\title{
Modelling of nutrient partitioning in growing pigs to predict their anatomical body composition. 1. Model description
}

\author{
V. Halas ${ }^{1}$, J. Dijkstra ${ }^{2}$, L. Babinszky ${ }^{1}$, M. W. A. Verstegen ${ }^{2}$ and W. J. J. Gerrits ${ }^{2}$ \\ ${ }^{1}$ University of Kaposvár, Faculty of Animal Science, Department of Animal Nutrition, P. O. Box 16, H-7400 Kaposvár, \\ Hungary \\ ${ }^{2}$ Animal Nutrition Group, Wageningen University and Research Centre, Zodiac, Marijkeweg 40, 6709 PG Wageningen, \\ The Netherlands
}

(Received 3 December 2003 - Revised 28 May 2004 - Accepted 16 June 2004)

\begin{abstract}
A dynamic mechanistic model was developed for growing and fattening pigs. The aim of the model was to predict growth rate and the chemical and anatomical body compositions from the digestible nutrient intake of gilts $(20-105 \mathrm{~kg}$ live weight). The model represents the partitioning of digestible nutrients from intake through intermediary metabolism to body protein and body fat. State variables of the model were lysine, acetyl-CoA equivalents, glucose, volatile fatty acids and fatty acids as metabolite pools, and protein in muscle, hide-backfat, bone and viscera and body fat as body constituent pools. It was assumed that fluxes of metabolites follow saturation kinetics depending on metabolite concentrations. In the model, protein deposition rate depended on the availability of lysine and of acetyl-CoA. The anatomical body composition in terms of muscle, organs, hide-backfat and bone was predicted from the chemical body composition and accretion using allometric relationships. Partitioning of protein, fat, water and ash in muscle, organs, hide-backfat and bone fractions were driven by the rates of muscle protein and body fat deposition. Model parameters were adjusted to obtain a good fit of the experimental data from literature. Differential equations were solved numerically for a given set of initial conditions and parameter values. In the present paper, the model is presented, including its parameterisation. The evaluation of the model is described in a companion paper.
\end{abstract}

Modelling: Anatomical body composition: Chemical body composition: Pig

Since the introduction of pig growth models, applicable in a scientific and a practical environment in the 1970s and 1980s (for example, see Whittemore \& Fawcett, 1976; Moughan et al. 1987; Black et al. 1988), interest in prediction of pig growth has increased over the years. New models have been introduced, each serving their own objective: some models have focused on nutrient digestion processes (Bastianelli et al. 1996), on protein digestion in the small intestine (Rivest et al. 2000) or on estimating amino acid requirements (Moughan, 1989). Others have aimed to model growth rate and its composition in terms of protein and lipid (Burlacu et al. 1989; Pomar et al. 1991; Danfaer, 2000; Birkett \& de Lange, 2001b), or especially fatty acid composition of the body fat (Lizardo et al. 2002), or improving understanding of different processes, such as protein turnover and ion pumping (Gill et al. 1989b), or the process of growth (Lovatto \& Sauvant, 2003). In addition, pig growth modelling efforts have been reviewed and various approaches have been discussed extensively (Black, 1995; Gerrits \& Dijkstra, 2000; Halas \& Babinszky, 2000; Birkett \& de Lange, 2001a). Most pig growth simulation models until the 1990s considered protein and energy as separate entities (de Lange, 1995).
As acknowledged in more recently developed models, this approach ignored the effects of differences in the composition of the dietary energy (Danfaer, 2000; Birkett \& de Lange, 2001a). In addition to models predicting chemical body composition, prediction of anatomical body composition is of great interest, relating chemical body composition to slaughter and meat quality. Anatomical body composition in this regard is defined as the proportion of muscle, bone, hide-backfat and organs in the body. Some research groups have developed models for the prediction of anatomical body composition, depending on feed intake and composition. These models are almost exclusively based on empirical relationships (e.g. Technisch Model Varkensvoeding, 1991). However, nutrients in the feed have to undergo hydrolysis before absorption may occur, and the absorbed nutrients follow different pathways. Consequently, simulation of use of nutrients for growth based on understanding of the processes and interactions involved, should, at least to some extent, make use of biochemical pathways (Gill et al. 1989a). Therefore, a biologically based approach to simulation of anatomical body composition follows nutrients from ingestion through intermediary metabolism to the deposition of chemical 
body fat and protein, preferably in distinct tissues or tissue groups. Thus in a mechanistic approach, prediction of anatomical body composition has to be based on deposition of chemical entities. The preferred level of aggregation chosen for the representation of (bio)chemical constituents depends on the model objectives and available data.

In the present paper, a mechanistic dynamic model is described, in which this approach was followed to predict the anatomical body composition of gilts between 20 and $105 \mathrm{~kg}$ live weight. The model is driven by nutrient intake, and predicts both chemical and anatomical body compositions. In the present paper, the model is presented, including its parameterisation. In a companion paper, an evaluation of the model is presented, including behavioural analysis, sensitivity analysis and comparison with independent data (Halas et al. 2004).

\section{Model description}

The process of growth is affected by genetics and environment, and particularly by nutrition. The present model focuses on the partitioning of nutrients in growing pigs. Representation of genders and genotypes is not part of the present model, but the consequences for the approach taken are discussed on p. 718. In the literature, there is no direct link from ingested nutrients to anatomical body composition on a biological basis. Macronutrients such as protein, lipids and carbohydrates are degraded to metabolites: e.g. amino acids, long-chain fatty acids and glucose. Through different pathways these metabolites are oxidised or deposited as body protein and body fat. Therefore, in the current model the prediction of anatomical body composition from nutrient intake involves two steps, which are referred to as 'metabolic' and 'anatomical' parts of the model. The approach used in the model is presented schematically in Fig. 1. In the metabolic part, absorbed nutrients enter the intermediary metabolism. The results of the intermediary metabolism in the model are the daily muscle protein and body fat deposition and the daily heat production. The equations established in this part of the model are commonly applied in enzyme kinetics (Gill et al. 1989a). In the anatomical part of the model, it is presumed that the muscle protein deposition rate determines the deposition rate of hide-backfat, organ and bone protein, and that the body fat deposition rate determines the fat deposition rate in hide-backfat, muscle and organs. Deposition of water and ash are related to protein deposition. All of these relationships are described by allometric equations. Anatomical body composition is defined as the proportion of muscle, bone (including head, feet and tail), hide-backfat (skin and subcutaneous fat) and organs (blood, viscera and leaf fat) in the body. The complete list of the model equations is given in appendix 1 .

\section{Representation of the metabolic part of the model}

The growth model is driven by digestible nutrient inputs; it describes the partitioning of nutrients from ingestion through intermediary metabolism into body stores. A diagrammatic representation of the metabolic part of the model is presented in Fig. 2. In empirical models, only protein and energy inputs are used to simulate growth of pigs (Halas et al. 2003). The present model uses nutrients derived from the digestion of protein, fat, starch and sugar and from fermentation of cell wall components. A continuous input of nutrients is assumed. Under practical circumstances, lysine is usually the limiting amino acid for protein deposition (Agricultural Research Council, 1981).

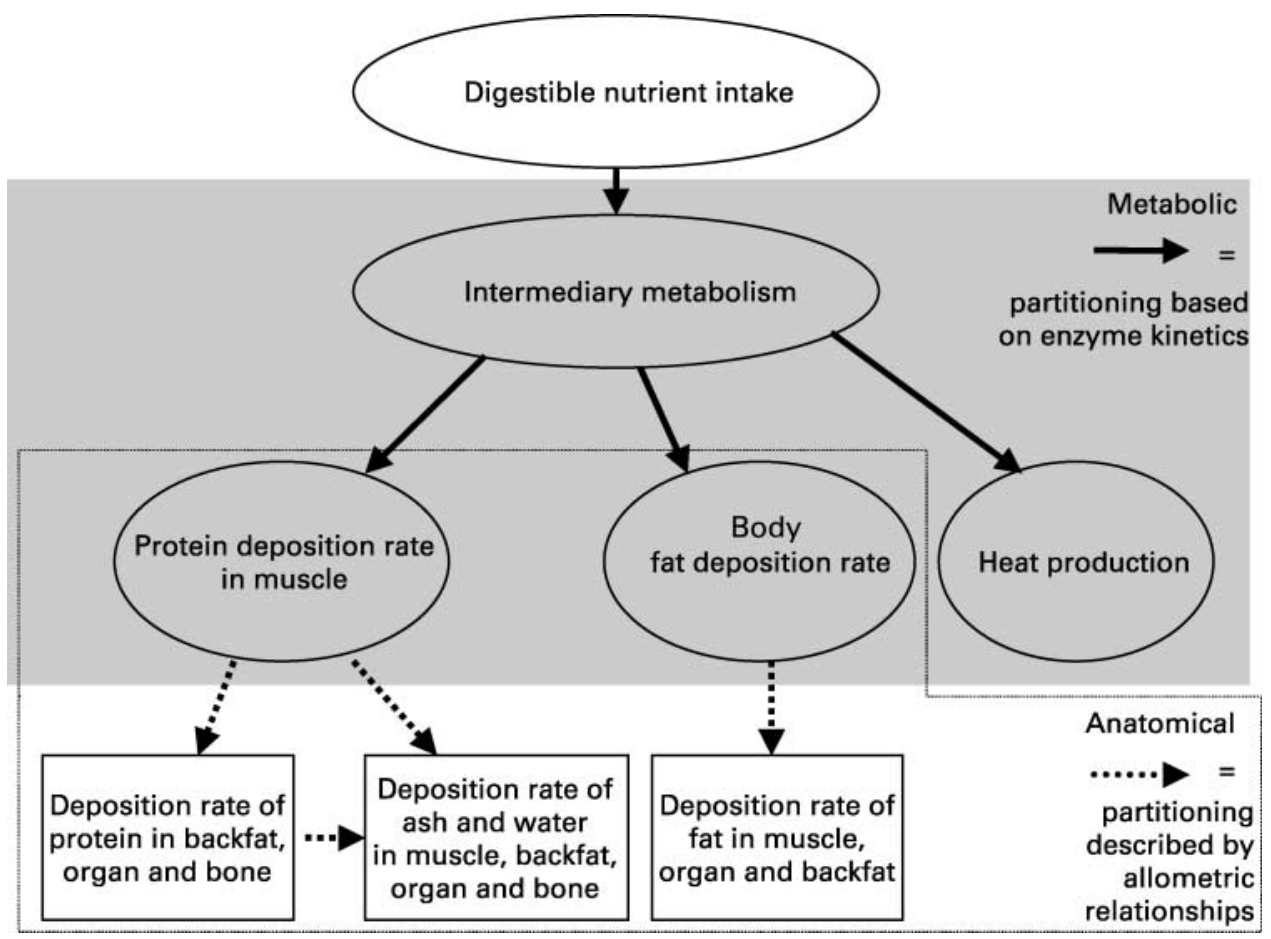

Fig. 1. Schematic representation of the model approach. 


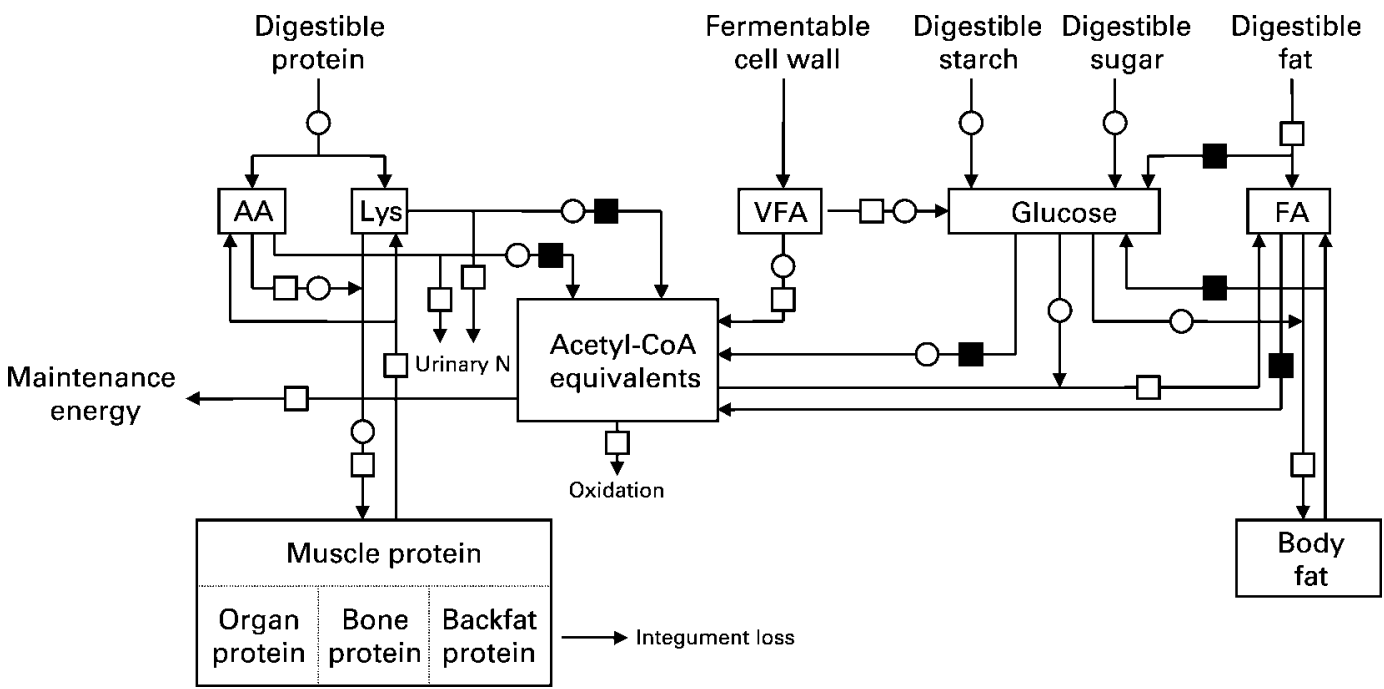

Fig. 2. Diagrammatic representation of the pig growth model. AA, amino acid; VFA, volatile fatty acid; FA, fatty acid. $O$, Energy use in transport; $\square$, energy use in reaction; $\mathbf{a}$, ATP production in reaction.

Therefore, lysine availability is assumed to be the amino acid that potentially limits the rate of protein synthesis. Body metabolite pools are lysine, acetyl-CoA, glucose, long-chain fatty acids and volatile fatty acids (VFA). The body storage pools comprise protein and lipid in bone, hide-backfat, organs and muscle.

In line with other mechanistic growth models in beef cattle (France et al. 1987), sows (Pettigrew et al. 1992) and preruminant calves (Gerrits et al. 1997), the majority of the flux equations are described using standard expressions from enzyme kinetics. The principle of the model is that net growth results from the balance between synthesis and degradation processes. It is assumed that synthesis depends on the concentration of substrates available and that the utilisation of metabolites follows saturation kinetics.

The rate of change of a pool with time is defined by the sum of all fluxes into and out of that pool. Actual pool sizes are the quantities of the metabolite (mol) or body store $(\mathrm{kg})$ calculated by integration of pool changes over time. Metabolite concentrations are calculated based on empty body weight. Indeed, in many reactions it is the metabolites present in the intracellular pool that act as substrates (Pettigrew et al. 1992). Metabolite concentrations, expressed per $\mathrm{kg}$ body weight, are, however, difficult to find in the literature. Therefore, normal concentrations in blood plasma were adopted to calculate initial metabolite pool sizes for lysine, glucose and fatty acids.

\section{Stoichiometry and model parameterisation}

The abbreviations used in the model are given in Tables 1 and 2; stoichiometric yield and requirement factors for protein and energy metabolism are shown in Tables 3 and 4 respectively. These factors include transport costs; absorption costs of the nutrients are considered explicitly. The yield factors of protein synthesis (Yi,lyi) and proteolysis (Yly,ily; Yaa,ily) and the amino acid requirements of protein synthesis (Raa,lyi) were calculated based on tissue amino acid composition data presented by Wünsche et al. (1983). In accordance with Gill et al. (1989b) and Gerrits et al. (1997), we presumed that the energy requirement is 4 mol ATP per peptide bond in protein synthesis. In previous models (Gill et al. 1984; Baldwin et al. 1987; Pettigrew et al. 1992) no energy costs were assumed for protein breakdown. However, utilisation of energy in hydrolysis of phosphate bonds appears essential to proteolysis. Rapoport et al. (1985) suggested a requirement of 1 mol ATP per peptide bond cleaved in reticulocytes. Gerrits et al. (1997) concluded from the literature that the ATP cost of

Table 1. Abbreviation of names for entities of the model

\begin{tabular}{|c|c|c|}
\hline Symbol & Entity & Unit \\
\hline aa & Amino acids others than lysine & $\mathrm{mol}$ \\
\hline at & ATP & $\mathrm{mol}$ \\
\hline ay & Acetyl-CoA & mol \\
\hline bf & Bone fat & $\mathrm{kg}$ \\
\hline bp & Bone protein & $\mathrm{kg}$ \\
\hline $\mathrm{cW}$ & Cell wall components & $\mathrm{kg}$ \\
\hline da & Dietary minerals & $\mathrm{kg}$ \\
\hline df & Dietary fat & $\mathrm{kg}$ \\
\hline $\mathrm{dp}$ & Dietary protein & $\mathrm{kg}$ \\
\hline ew & Empty body weight & $\mathrm{kg}$ \\
\hline ex & Exogenous protein loss (skin and hair) & $\mathrm{kg}$ \\
\hline fa & Fatty acid & mol \\
\hline gl & Glucose & $\mathrm{mol}$ \\
\hline $\mathrm{gr}$ & Additional cost for growth & $\mathrm{mol}$ ay/d \\
\hline hf & Hide-backfat fat & $\mathrm{kg}$ \\
\hline $\mathrm{hp}$ & Hide-backfat protein & $\mathrm{kg}$ \\
\hline li & Liver mass & $\mathrm{kg}$ \\
\hline Iw & Live weight & $\mathrm{kg}$ \\
\hline ly & Lysine & mol \\
\hline $\mathrm{ma}$ & Maintenance requirement & $\mathrm{molay} / \mathrm{d}$ \\
\hline $\mathrm{mf}$ & Muscle fat & $\mathrm{kg}$ \\
\hline $\mathrm{mp}$ & Muscle protein & $\mathrm{kg}$ \\
\hline of & Organ and abdominal fat & $\mathrm{kg}$ \\
\hline op & Organ protein & $\mathrm{kg}$ \\
\hline ox & Oxidation of acetyl-CoA & mol \\
\hline st & Starch & $\mathrm{kg}$ \\
\hline su & Sugar & $\mathrm{kg}$ \\
\hline ta & Total body ash & $\mathrm{kg}$ \\
\hline tf & Total fat mass & $\mathrm{kg}$ \\
\hline un & Urinary $\mathrm{N}$ & $\mathrm{mol}$ \\
\hline vf & Volatile fatty acids & $\mathrm{mol}$ \\
\hline
\end{tabular}


Table 2. Notation of the model

\begin{tabular}{|c|c|c|}
\hline Notation & Translation & Units \\
\hline $\mathrm{Ai}$ & Absorption cost for $i$ & $\mathrm{molay} / \mathrm{kg} i$ or $\mathrm{molay} / \mathrm{mol} i$ \\
\hline $\mathrm{Ci}^{*}$ & Concentration of $i$ & $\mathrm{~mol} i / \mathrm{kg}$ ew or $\mathrm{g} i / \mathrm{kg}$ diet \\
\hline $\mathrm{Di}$ & Digestibility of nutrients & - \\
\hline FDRi & Fractional degradation rate of $i$ & $d^{-1}$ \\
\hline $\mathrm{Ji}, \mathrm{jk}$ & Michaelis-Menten inhibition constant for $j-k$ transaction with respect to $i$ & $\mathrm{~mol} / \mathrm{kg}$ \\
\hline $\mathrm{Mi}, \mathrm{jk}$ & Michaelis-Menten affinity constant for $j-k$ transaction with respect to $i$ & $\mathrm{~mol} / \mathrm{kg}$ \\
\hline $\mathrm{Pi}, \mathrm{jk}$ & Rate of production of $i$ by $j-k$ transaction & $\mathrm{mol} / \mathrm{d}$ or $\mathrm{kg} / \mathrm{d}$ \\
\hline Qi & Quantity of $i$ & $\mathrm{~mol}$ or $\mathrm{kg}$ \\
\hline $\mathrm{Ri}, \mathrm{jk}$ & Requirement of $i$ in $j-k$ transaction & $\mathrm{mol} i / \mathrm{mol}$ or $\mathrm{kg} j$ \\
\hline Sjk & Steepness parameter for $j-k$ transaction & - \\
\hline Ui,jk & Rate of utilization of $i$ by $j-k$ transaction & $\mathrm{mol} / \mathrm{d}$ or $\mathrm{kg} / \mathrm{d}$ \\
\hline Vjk & Maximum rate of velocity for $j-k$ transaction & $\mathrm{mol} / \mathrm{kg}^{0.75}$ per $\mathrm{d} \dagger$ \\
\hline$Y i, j k$ & Yield of $i$ in $j-k$ transaction & $(\mathrm{mol}$ or $\mathrm{kg} i) /(\mathrm{mol}$ or $\mathrm{kg} j)$ \\
\hline
\end{tabular}

proteolysis varies, depending on the mechanism involved. As an average, an energy cost of 1 mol ATP per peptide bond cleaved was assumed. The energy cost of urea synthesis ( $4 \mathrm{~mol}$ ATP/mol urea) is included in the energy yield of amino acid oxidation.

The yield factors of the energy metabolism and the energy and glucose requirements in the model are presented in Table 4. Some transactions, like body fat synthesis, have different stoichiometric parameters, such as yield of body fat from fatty acids (Ytf,fatf; $\mathrm{kg} / \mathrm{mol}$ ), glucose requirement of fat synthesis (Rgl,fatf; mol/mol) and acetyl-CoA requirement of fat synthesis (Ray,fatf; mol/ $\mathrm{mol})$. The units of yield and requirement factors depend on the representation of the state variables, viz. mol for intermediary metabolites and $\mathrm{kg}$ for nutrient intakes and body storage pools. An example is given on the calculation routine of different values. The yield factor of fatty acid produced from body fat (Yfa,tffa) is 3.394, which means that 3.394 mol fatty acid can be produced from $1 \mathrm{~kg}$ body fat. This value is calculated based on the assumptions that an average fatty acid in body fat has a molecular mass of $282 \mathrm{~g} / \mathrm{mol}$ and that body fat consists of triacylglyerol with a total molecular mass (after hydrolysis) of $882 \mathrm{~g} / \mathrm{mol}$. All data in the table were calculated based on molecular mass, energy yield per mol substrate, average $\mathrm{N}$ content and transport costs. The absorption costs were taken from previous models (Gill et al. 1989b; Pettigrew et al. 1992; Gerrits et al.
1997). It was assumed that each mol glucose or amino acid absorbed from the gut requires 0.33 mol ATP. Similarly, transport of glucose or amino acids through membranes other than those in the intestinal wall requires the same amount of energy. It was also assumed that dietary fat is absorbed as monoacylglycerol and two fatty acids. Subsequent re-esterification to yield a triacylglycerol costs $1.33 \mathrm{~mol} \mathrm{ATP/fatty} \mathrm{acid} \mathrm{equivalent} \mathrm{(Gerrits} \mathrm{et} \mathrm{al.}$ 1997). Re-esterification maintains an inward diffusion gradient, so no extra absorption costs are assumed. Excretion of urea in urine is assumed to require $8.78 \mathrm{~kJ} / \mathrm{mol}$ urea (Martin \& Blaxter, 1965) or, assuming that 1 mol ATP is $79 \mathrm{~kJ}$ and that $12 \mathrm{~mol}$ ATP are formed per unit of acetyl-CoA, the requirement of acetyl-CoA for urea excretion per mol urea $\mathrm{N}$ (Ray,lyun and Ray,aaun) is $0.0046 \mathrm{~mol}$ acetyl-CoA $/ \mathrm{mol}$ urea $\mathrm{N}$.

Associated energy costs of bone mineralisation are assumed to be small, because ash deposition is low compared with deposition of the other chemical components. In the present model, the energy costs of bone mineralisation are assumed to be proportional to $\mathrm{Ca}$ and $\mathrm{P}$ deposition in bone tissue. The average $\mathrm{Ca}$ and $\mathrm{P}$ contents are 376 and $184 \mathrm{~g} / \mathrm{kg}$ ash fraction in pig bone (Larsen et al. 2000). As suggested by Gerrits et al. (1997), $2 \mathrm{~mol} \mathrm{ATP/mol} \mathrm{Ca}$ and $\mathrm{P}$ incorporated in bone ash is assumed.

Parameters to be quantified in the fluxes are the maximum velocity of the reaction $\left(V_{\max }\right)$, the affinity (Mijk) and inhibition constants (Jiji) and the steepness

Table 3. Stoichiometry of protein turnover

\begin{tabular}{|c|c|c|c|c|}
\hline Synthesis & Yi,lyi (kg i/mol ly)† & Ray,lyi (mol ay/mol ly)† & Raa,lyi (mol aa/mol ly)† & Ray,aai (mol ay/mol aa) $†$ \\
\hline Muscle protein & $1 \cdot 6497$ & 0.361 & $10 \cdot 8965$ & 0.361 \\
\hline Organ protein & 1.6404 & 0.361 & $10 \cdot 9886$ & 0.361 \\
\hline Hide-backfat protein & 3.1739 & 0.361 & $26 \cdot 8519$ & 0.361 \\
\hline Bone protein & $3 \cdot 1064$ & 0.361 & $25 \cdot 3024$ & 0.361 \\
\hline Degradation & Yly,ily (mol ly/kg i)† & Ray,ily (mol ay/kg i)† & Yaa,ily (mol aa/kg i)† & Ray, iaa (mol ay/kg i)† \\
\hline Muscle protein & 0.6062 & 0.051 & $6 \cdot 6051$ & 0.550 \\
\hline Organ protein & 0.6096 & 0.051 & 6.6985 & 0.558 \\
\hline Hide-backfat protein & 0.3151 & 0.026 & 8.4602 & 0.705 \\
\hline Bone protein & 0.3219 & 0.027 & $8 \cdot 1453$ & 0.679 \\
\hline
\end{tabular}

* For details of notations and abbreviations, see Tables 1 and 2

$\dagger i$ is muscle, organ, hide-backfat or bone protein. 
Table 4. Stoichiometry of the energy metabolism not related to protein turnover*

\begin{tabular}{|c|c|c|c|c|c|c|}
\hline $\begin{array}{l}\text { Transaction } \\
(j-k)\end{array}$ & $\begin{array}{c}\mathrm{Yk}, \mathrm{jk} \\
(\mathrm{mol} / \mathrm{mol}) \dagger\end{array}$ & $\begin{array}{c}\text { Yat,jk } \\
(\mathrm{mol} / \mathrm{mol}) \dagger\end{array}$ & $\begin{array}{c}\mathrm{Rgl}, \mathrm{jk} \\
(\mathrm{mol} / \mathrm{mol}) \dagger\end{array}$ & $\begin{array}{c}\text { Ray,jk } \\
(\mathrm{mol} / \mathrm{mol}) \dagger\end{array}$ & $\begin{array}{c}\text { Yun,jk } \\
(\mathrm{mol} / \mathrm{mol}) \dagger\end{array}$ & $\begin{array}{c}\text { Ygl,jk } \\
(\mathrm{mol} / \mathrm{kg}) \dagger\end{array}$ \\
\hline ly-ay & 1.973 & $12 \cdot 00$ & & & 2.000 & \\
\hline ly-un & & & & 0.0046 & & \\
\hline aa-ay & 0.780 & 14.07 & & & 1.456 & \\
\hline aa-un & & & & 0.0046 & & \\
\hline fa-ay & 9.000 & 36.00 & & & & \\
\hline gl-ay & 1.973 & 14.00 & & & & \\
\hline vf-ay & 1.000 & & & & & \\
\hline $\mathrm{df}-\mathrm{fa}$ & 3.394 & $2 \cdot 26$ & & & & 0.566 \\
\hline $\mathrm{tf}-\mathrm{fa}$ & 3.394 & $2 \cdot 26$ & & & & 0.566 \\
\hline ay-fa & 0.102 & & 0.157 & & & \\
\hline $\mathrm{fa}-\mathrm{tf}$ & 0.295 & & 0.167 & 0.282 & & \\
\hline st-gl & $6 \cdot 173$ & & & & & \\
\hline su-gl & $5 \cdot 55$ & & & & & \\
\hline vf-gl & 0.500 & & & & & \\
\hline $\mathrm{da}-\mathrm{ta}$ & & & & 2.555 & & \\
\hline st-vf & $8 \cdot 642$ & & & & & \\
\hline$c w-v f$ & $7 \cdot 778$ & & & & & \\
\hline Aly & & & & 0.0275 & & \\
\hline Aaa & & & & 0.0275 & & \\
\hline Agl & & & & 0.0275 & & \\
\hline Afa & & & & 0.1108 & & \\
\hline
\end{tabular}

${ }^{*}$ For details of notations and abbreviations, see Tables 1 and 2.

†The unit is $\mathrm{mol} / \mathrm{kg}$ in cases of yield of fatty acid in body fat (Yfa,tfa) and dietary fat degradation (Yfa,dffa), yield of volatile fatty acids from dietary starch (Yvf,stvf) and cell wall (Yvf,cwvf) and mineral incorporation (Yta,data); the unit is $\mathrm{kg} / \mathrm{mol}$ in case of yield of body fat synthesised from fatty acids (Ytf,fatf).

parameters (Sij) (Table 5). Since there are no existing models for growing and fattening pigs with our approach, we calibrated these parameters on experimental data (Bikker et al. 1994, 1995, 1996a,b; P Bikker, unpublished results), as described later. For the calculation of $V_{\max }$ values, it was assumed that the $V_{\max }$ of a certain transaction is proportional to the tissue mass where the transaction takes place. The $V_{\max }$ values were mainly calculated from experimental data. These data, however, are most certainly an underestimate of the theoretical $V_{\max }$, because in in vivo experiments conditions will never be optimal (Gill et al. 1989a). In order to approach realistic $V_{\max }$, each value obtained was arbitrarily increased by $25 \%$. Subsequently, affinity and inhibition constants and steepness parameters were adjusted to obtain a good fit of the experimental data regarding the measured average muscle protein and body fat deposition rates, as discussed later.

Table 5. Maximum velocity $\left(\mathrm{Vjk}, \mathrm{mol} / \mathrm{kg}^{0.75}\right.$ per d), steepness parameter $(\mathrm{Sjk})$, affinity $(\mathrm{Mijk}, \mathrm{mol} / \mathrm{kg})$ and inhibition constant $(\mathrm{Jkjk}$ $\mathrm{mol} / \mathrm{kg}$ ) of transactions*

\begin{tabular}{lcllll}
\hline Transaction $\dagger$ & Vjk & Sjk & \multicolumn{1}{c}{ Mijk } & May,jk & Jkjk \\
\hline Ly,lymp & 0.0423 & 1.5 & 0.00001 & 0.00025 & \\
Ly,lyay & 0.4932 & 2 & 0.00015 & & \\
Fa,fatf & 0.2882 & & 0.0009 & & 0.0003 \\
Fa,faay & 0.1207 & & 0.005 & & 0.1 \\
Ay,ayfa & 2.5266 & & 0.004 & & \\
Ly,aygr & 1.1885 & & 0.0001 & 0.006 & \\
Gl,glay & 0.5532 & & 0.005 & & \\
Vf,vfay & 0.1551 & & 0.0005 & & \\
\hline
\end{tabular}

* For details of notations and abbreviations, see Tables 1 and 2.

† The unit of Vaygr is $\mathrm{mol} / \mathrm{kg}^{0.67}$ per d; the unit of Vfatf is $\mathrm{mol} / \mathrm{kg}$ per $\mathrm{d}$.

\section{Protein metabolism}

Lysine pool (Qly). The inputs to the lysine pool are from the apparent absorption of dietary ileal digestible lysine (equation 1.2) and from body protein degradation (equations 1.3-1.6). The outputs from the pool are to protein synthesis (equations $1.7-1.10$ ) and to acetyl-CoA production (equation 1.11). Initial pool concentration is $0.1 \mathrm{mmol} / \mathrm{kg}$ (Defa et al. 1999). The utilisation of lysine to protein synthesis is driven by lysine and acetyl-CoA concentrations (equation 1.7). The reason for the acetylCoA dependency of the transaction is that protein synthesis may be limited by energy supply according to the linearplateau concept (Bikker et al. 1994; Campbell et al. $1984,1985)$. The site of the muscle protein synthesis is located in muscle protein. The $V_{\max }$ of the transaction is therefore scaled with muscle protein mass (Qmp) as $\mathrm{Qmp}^{0.75}$ (equation 1.7). The $V_{\max }$ for muscle protein synthesis was set as follows: the maximum rate of protein deposition in the experiment of Bikker et al. (1996a) of $190 \mathrm{~g} / \mathrm{d}$ (ad libitum feed intake; averaged over $45-85 \mathrm{~kg}$ ) was assumed to correspond to a maximum of $150 \mathrm{~g} / \mathrm{d}$ at $50 \mathrm{~kg}$ body weight. According to Simon (1989), half the body protein deposition rate was considered to be muscle protein $(75 \mathrm{~g} / \mathrm{d})$. The fractional degradation rate (FDR) of muscle protein was set as $2.23 \% / d$ (see later), which results in $111.5 \mathrm{~g}$ muscle protein degradation/d. Utilisation of lysine in muscle protein synthesis is computed as the daily rate of muscle protein synthesis (summing up the daily deposition and degradation) divided by the yield factor of muscle protein produced from $1 \mathrm{~mol}$ lysine (Yly,mply; see equation 3.1). Subsequently $0.0338 \mathrm{~mol} /$ Qmp $^{0.75}$ per d was obtained for $V_{\max }$, and that value was increased by $25 \%$ as discussed earlier. 
The same approach was adopted for lysine oxidation, assuming that the concentration of lysine influences its oxidative metabolism (equation 1.11). The size of the reaction site was scaled with liver weight $\left(\mathrm{Qli}^{0 \cdot 75}\right)$, as the catabolism of lysine takes place mainly in the liver (Nelson \& Cox, 1982). The liver mass was obtained from organ protein mass (equation 13.2). By oxidation, lysine yields acetyl-CoA (equation 1.11), some ATP (equation 7.13) and urinary $\mathrm{N}$ (equation 7.19). The $V_{\max }$ of the lysine oxidation was assumed to equal the whole-body lysine flux, i.e. the sum of lysine from degraded body proteins and ileal digestible lysine intake. In the case of a pig of $50 \mathrm{~kg}$ body weight, body protein mass is approximately $10 \mathrm{~kg}$. It is split among muscle, organs, hide-backfat and bone (50, 15, 25 and $10 \%$ respectively; Simon, 1989). The amount of lysine released from degradation of muscle, hide-backfat, organ and bone protein was $0.2636 \mathrm{~mol} / \mathrm{d}$. It was presumed that $2.5 \mathrm{~kg}$ feed intake with $160 \mathrm{~g} / \mathrm{kg}$ digestible protein content and $0.6075 \mathrm{~mol}$ lysine $/ \mathrm{kg}$ protein yields $0.2430 \mathrm{~mol}$ lysine/d. Therefore, $V_{\max }$ for lysine oxidation was set to $0.3946 \mathrm{~mol}$ lysine/Qli ${ }^{\circ .75}$ per d (see equation 13.2 for Qli) and the obtained $V_{\max }$ was increased by $25 \%$ as mentioned earlier.

Amino acid pool (Qaa). The inputs to the amino acid pool are from apparent absorption of dietary ileal digestible protein (equation 2.1) and from body protein degradation (equations 2.2-2.5). The average molecular mass of the amino acids other than lysine in dietary, muscle, organ, bone and hide-backfat protein are assumed to be 130, 138, 136, 117 and $113 \mathrm{~g} / \mathrm{mol}$ respectively (Wünsche et al. 1983). Outputs are to protein synthesis (equations 2.6-2.9) and acetyl-CoA (equation 2.10). The utilisation of amino acids for protein synthesis depends on utilisation of lysine for protein synthesis. For reasons of simplicity, all amino acids not used for protein synthesis are assumed to be catabolised to yield acetyl-CoA (equation 2.10), ATP (equation 7.14) and urinary $\mathrm{N}$ (equation 7.20). Consequently the change of amino acid pool size in time is zero (equation 2.11) and is a zero-pool (Baldwin et al. 1987).

Muscle protein pool (Qmp). The muscle protein pool represents approximately half the body protein (Simon, 1989). The synthesis of muscle protein is dependent on lysine and acetyl-CoA concentrations. The turnover of the muscle protein can be manipulated by nutrition. Both synthesis and degradation increase with increasing nutrient supply as reviewed by Halas et al. (2003). A high protein turnover due to the excess nutrient supply results in a high protein deposition rate. For reasons of simplicity, the FDR is considered to be constant for each protein pool in the model (equations 3.2, 4.2, 5.2, 6.2). The FDR of muscle protein was assumed to be $2.23 \% / \mathrm{d}$ (van den Hemel-Grooten, 1996). Values in the literature vary between 2 and $4 \% / \mathrm{d}$ depending on nutrient supply and experimental method used (Mulvaney et al. 1985; Bergen et al. 1989; Simon, 1989; Rathmacher et al. 1996). The $V_{\max }$ for muscle protein synthesis was calculated as follows. The lysine needed for maximum muscle protein deposition at $50 \mathrm{~kg}$ live weight $(75 \mathrm{~g} / \mathrm{d})$ and the lysine yielded from daily muscle protein degradation $(112 \mathrm{~g} / \mathrm{d})$ were added up and divided by $\mathrm{Qmp}^{0.75}$. As discussed earlier, the value was increased by $25 \%$ to approach a realistic $V_{\max }$.
In the model, the deposition rate of protein in organs, hide-backfat and bone are related to the deposition rate of muscle protein (Fig. 3). These relationships were estimated from a serial slaughter experiment of pigs from 20 to $105 \mathrm{~kg}$ body weight (P Bikker, unpublished results; see p. 714).

Organ protein pool (Qop). Literature data shows that the organ protein pool is characterised by a very high turnover rate, with fractional synthesis and degradation rates close to each other. The fractional protein synthesis rate is reported to vary between $12-60 \% / \mathrm{d}$ in $50 \mathrm{~kg}$ pigs, depending on the organ and on the method used (Riis, 1983; Simon, 1989). In the model, an average value of $17.8 \% / d$ was adopted for FDR in organ fraction. The rate of organ protein synthesis (equation $4.1 ; \mathrm{kg} / \mathrm{d}$ ) is calculated as the sum of net accretion (Fig. 3) and degradation rates. The organ protein breakdown rate is calculated from the pool size and fractional degradation (equation 4.2).

Hide-backfat protein pool (Qhp). The hide-backfat protein pool has a relatively low turnover rate, even lower than that of muscle protein. The fractional synthesis rate is about $5 \% / d$ (Riis, 1983; Simon, 1989). According to that value, the FDR of hide-backfat protein was calculated from the experiments as a corresponding FDR of $2 \% / \mathrm{d}$. Outputs from this pool are from degradation of hide-backfat protein (equation 5.2) and through losses of protein by skin and hair (equation 5.3). Protein losses by skin and hair are related to metabolic body weight and adopted from Moughan (1989) as $0.094 \mathrm{~g} / \mathrm{kg}^{0.75}$ per d (equation 5.3). The rate of hide-backfat protein synthesis was calculated by summation of the rate of hide-backfat protein deposition (depending on muscle protein deposition rate, Fig. 3), hide-backfat protein degradation and hair and skin protein losses (equation 5.1).

Bone protein pool $(\mathrm{Qbp})$. According to the literature data, the FDR of bone protein between 20 and $120 \mathrm{~kg}$ body weight was estimated at $5 \% / d$ (Riis, 1983; Simon, 1989). Similar to the other protein pools, the rate of protein synthesis is calculated from rate of bone protein accretion (depending on muscle protein accretion rate, Fig. 3) and rate of protein degradation (equation 6.1).

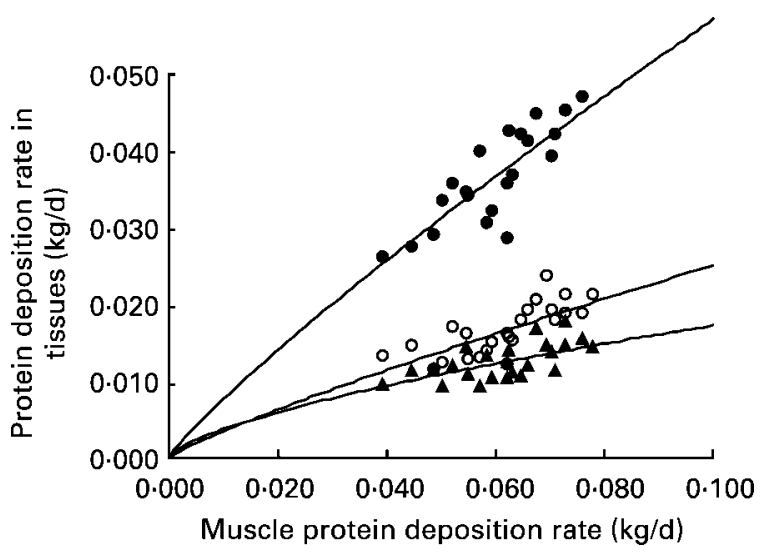

Fig. 3. Partitioning of protein deposition rates in hide-backfat $(\bullet)$, organs $(\circ)$ and bone $(\mathbf{\Lambda})$ as a function of muscle protein deposition rate. The relationships were estimated from the data of $P$ Bikker (unpublished results). For details of procedures, see pp. 714-715. 


\section{Energy metabolism}

The energy metabolism covers all of the transactions that are involved in the energy production and protein and fat accretion. For reasons of simplicity and as discussed by Gerrits et al. (1997), energy is supplied by oxidation of acetyl-CoA. In some energy-yielding transactions, direct production of ATP is also indicated (see Table 4). Following standard biochemistry, $1 \mathrm{~mol}$ acetyl-CoA is equivalent to 12 mol ATP (Stryer, 1981).

Acetyl-CoA pool (Qay). The inputs to the acetyl-CoA pool are from the oxidation of lysine (equation 7.2), amino acids (equation 7.3), fatty acids (equation 7.4) and glucose (equation 7.5). The acetic and butyric acid absorbed from the gut are considered to appear as acetylCoA (equation 7.6). The rate of production of acetyl$\mathrm{CoA}$ is determined by the rate of utilisation of the metabolites. The outputs of the pool are utilisation for fatty acid synthesis (equation 7.7), and to provide energy for all energy-requiring transactions (equations 7.9, 7.10), including maintenance energy (equation 7.12). The initial pool concentration was set arbitrarily to $3 \mathrm{mmol} / \mathrm{kg}$.

In de novo fatty acid synthesis, non-lipid nutrients are converted to fatty acids via acetyl-CoA. Similar to the model of Gerrits et al. (1997), it is assumed that fatty acid synthesis follows saturation kinetics and is inhibited by the endproduct formed. Fatty acid synthesis takes place in adipose tissue (Nürnberg \& Wegner, 1990). Therefore, the $V_{\max }$ for fatty acid synthesis is scaled by body fat mass $\left(\mathrm{Qtf}^{0.75}\right.$ ) (equation 7.7). The $V_{\max }$ of the transaction was arbitrarily set to enable a de novo rate of fatty acid synthesis of $680 \mathrm{~g} / \mathrm{d}$ for a pig of $100 \mathrm{~kg}$ body weight comprising $25 \mathrm{~kg}$ body fat, sufficient to provide $80 \%$ of the total fat synthesis rate of $850 \mathrm{~g} / \mathrm{d}$ (derived from P Bikker, unpublished results). The value obtained was increased by $25 \%$ to approach the realistic $V_{\max }$.

In several models, it has been shown that the approach chosen for representation of maintenance energy requirements has a significant impact on the simulation results (e.g. Gerrits et al. 1997). Baldwin et al. (1987) and Gerrits et al. (1997) used empirical relationships derived originally by Smith (1970) to estimate basal energy expenditure of lean body mass, body fat and viscera. By that approach, the difference in maintenance requirements among genotypes and genders can be explained better than by the use of fixed energy requirements per unit metabolic weight in current energy systems (e.g. Agricultural Reseach Council, 1981), as discussed by Noblet et al. (1999) and Schinckel \& de Lange (1996). Pettigrew et al. (1992) modified the equation of Baldwin et al. (1987), and related the maintenance energy requirement to protein in lean body and in viscera and to body fat mass, rather than tissues. In the present model the latter approach, taken from Pettigrew et al. (1992) was adopted (equation 7.12). The tissue maintenance energy costs include the cost of membrane transport and of substrate cycling, such as protein and fat turnover. The energy costs of these transactions are explicitly represented in the present model. Reeds et al. (1987) suggested that protein turnover represented 15-25\% total basal energy expenditure. Similarly, Gill et al. (1989b) assumed that $20 \cdot 6 \%$ total ATP expenditure was associated with muscle protein turnover in their model (taken from Reeds et al. 1985). Since in the present model maintenance expenditure includes tissue turnover, part of the maintenance energy requirement is accounted for twice. Therefore, arbitrarily, the maintenance requirement was reduced by $20 \%$. It should be emphasised, however, that this was done before fitting the model to the experimental data of Bikker et al. (1994, 1995, 1996a,b; P Bikker, unpublished results). It is important that all energy costs are quantitatively accounted for, although it is difficult to accurately assign them to the biological process represented in the model or to a lump sum, like maintenance energy requirement or additional energy costs of growth (described later).

Some transactions yield ATP as oxidation of lysine, amino acid, glucose and fatty acids (equations 7.13, 7.14, 7.16 and 7.18), and glucose production from dietary or body fat (equations 7.15 and 7.17). However, ATP was not represented as a state variable. Because ATP cannot be used as a substrate, the inevitable ATP production from equations mentioned earlier was used to satisfy maintenance energy requirements. In test simulations, it was confirmed that the sum of ATP-yielding transactions is always lower than the maintenance energy requirements (equation 7.8). The remaining maintenance energy requirements were satisfied by oxidation of acetyl-CoA.

An additional energy-requiring transaction was introduced and referred to as additional energy costs for growth (equation 7.10). This flux represents the energy costs of tissue deposition, not represented by the biological processes explicitly represented in the model. For example, the energy requirements for ion pumping, synthesis of endogenous protein and some other substrate cycling costs, are not represented by the model. The rate of acetyl-CoA oxidation satisfying these additional costs for growth depends on both acetyl-CoA and lysine concentration (equation 7.11). The $V_{\max }$ and the affinity parameters of the flux were set to cover the discrepancy between the energy utilisation accounted for in the model and the observed energetic efficiency in the trials used to calibrate the model. The $V_{\max }$ is assumed to be related to empty body weight (Qew $\left.{ }^{0.67}\right)$, being the site of the biological processes represented by this flux.

Volatile fatty acid pool (Qvf). The input to this pool is from VFA that arise from fermentation of cell wall components, mainly in the hindgut (equation 8.2). The outputs from the VFA pool are to the acetyl-CoA pool (in the form of acetate and butyrate, equation 8.3) and to glucose (in the form of propionate, equation 8.4). The default VFA ratio in the model is $70 \%$ acetic acid+butyric acid (PRayvf $=0.7$ ) and $30 \%$ propionic acid (Kennelly et al. 1981; Michael \& Rerat, 1998). The utilisation of VFA depends on the VFA concentration and is scaled with empty body weight $\left(\right.$ Qew $\left.{ }^{0.75}\right)$. The $V_{\max }$ was set to account for complete clearance of VFA on a high-fibre diet corresponding to $300 \mathrm{~g}$ daily intake of fermentable cell wall components. The obtained $V_{\max }$ was increased by $25 \%$. The initial VFA concentration was set to $0.1 \mathrm{mmol} / \mathrm{kg}$. The VFA concentration was assumed to be lower than in sows. Hence, the initial acetic acid concentration of $0.3 \mathrm{mmol} / \mathrm{kg}$ in sow model of Pettigrew et al. (1992) was reduced. 
Glucose pool $(Q g l)$. The glucose pool has a high turnover rate. Glucose is produced from dietary starch (equation 9.2) and sugars (equation 9.3) directly from the VFA pool (propionate only, equation 9.5) and from glycerol released from degraded dietary (equation 9.4) and body (equation 9.6) fat. It is assumed that the molecular mass of sugars is 180 and that of starch is $162 \mathrm{~g} / \mathrm{mol}$. The outputs of the glucose pool are used directly for oxidation (equation 9.7) and indirectly for fatty acid (through NADPH, equation 9.8) and fat synthesis (as glycerol, equation 9.9). Glucose is used as a source of glycerol in the esterification of fatty acids during fat synthesis (equation 9.8) and as the major source of reduced $\mathrm{NADPH}$ in fatty acid synthesis (equation 9.9) (Wijayasinghe et al. 1986). It is assumed that in non-ruminant animals, usually with sufficient quantities of glucose, all the required NADPH is produced by metabolism of glucose through the pentose phosphate pathway (Pettigrew et al. 1992). The $V_{\max }$ of the glucose oxidation was calculated for a pig of $50 \mathrm{~kg}$ body weight, assuming that all of the glucose inflow can be oxidised after supplying the glucose requirement of $400 \mathrm{~g} / \mathrm{d}$ fat synthesis. Assuming a maximum absorption of $750 \mathrm{~g}$ glucose $/ \mathrm{kg}$ diet, this yields $8.278 \mathrm{~mol}$ glucose per $\mathrm{d}$. The $V_{\max }$ of glycolysis is scaled with Qew ${ }^{0.75}$ (equation 9.7) and increased by $25 \%$. The initial glucose concentration was set at $4 \mathrm{mmol} / \mathrm{kg}$ (Stangl et al. 1999). Glucose synthesis from glucogenic metabolites other than propionate are not included in the model. In line with the sow model of Pettigrew et al. (1992), it was presumed that non-ruminant animals absorb most of their energy as glucose, and there was therefore no need for significant gluconeogenesis to occur from amino acids. On the other hand glucogenic amino acids degraded are passing through the glucose pool just to be oxidised later in the acetyl-CoA pool. This process is already represented in the model. Aggregation of the steps in this reaction (glucogenic amino acids via glucose to acetyl-CoA) will reduce the complexity of the model. Thus, we considered no explicit gluconeogenesis from amino acids in the model.

Fatty acid pool ( $Q f a)$. The inputs to the fatty acid pool are from dietary and body lipid hydrolysis (equations 10.2 and 10.3 respectively) and de novo synthesis (equation 10.4). In the interest of simplicity, the degraded dietary and body lipids are considered to produce $3 \mathrm{~mol}$ fatty acids and $0.5 \mathrm{~mol}$ glucose per mol lipid. Outputs are to body fat synthesis (equation 10.5) and fatty acid oxidation (equation 10.6). The molar weight of fatty acids is set as $282 \mathrm{~g}$, and initial pool concentration is $0.7 \mathrm{mmol} / \mathrm{kg}$ (Stangl et al. 1999). Fatty acid oxidation increases with increasing fatty acid concentration and is inhibited by acetyl-CoA concentration (equation 10.6). The $V_{\max }$ of that energy-yielding process is scaled with Qew ${ }^{0.75}$. The $V_{\max }$ for fatty acid oxidation was set to enable quantitative oxidation of all fatty acids absorbed from a high-fat diet and those released during lipolysis, assuming no re-utilisation of fatty acid to body fat. For this calculation, the dietary fat content and rate of lipolysis were assumed to be $160 \mathrm{~g} / \mathrm{kg}$ and $260 \mathrm{~g} / \mathrm{d}$ respectively. Body fat synthesis depends on fatty acid concentration, and $V_{\max }$ is scaled with body fat mass (Qtf) (equation 10.5). The $V_{\max }$ of body fat synthesis was set to $600 \mathrm{~g}$ fat/d for a pig of $100 \mathrm{~kg}$ (P Bikker, unpublished results), assuming a fixed FDR of $1 \%$ (see later). The $V_{\max }$ of fatty acid oxidation and body fat synthesis were increased by $25 \%$ to approach the realistic $V_{\max }$.

Body fat pool (Qtf). The body fat pool has one input, viz. synthesis of fat from fatty acids (equation 11.1), and one output, viz. degradation of fat (equation 11.2). The body fat pool represents chemically determined fats, assumed to comprise only triacylglycerol with a molar weight of $884 \mathrm{~g}$. Danfaer (1999) reported that the FDR of lipolysis in adipose tissue was $0.9 \% / \mathrm{d}$. This, a fixed FDR of $1 \% / \mathrm{d}$ was used in the model for the body fat.

\section{Representation of the anatomical part of the model}

\section{Prediction of tissue accretion}

Nutrient intake affects whole-body protein and lipid gain, but also the partitioning into body compartments. Variation in nutrient intake results in different accretion rates of tissues and organs and consequently in differences in anatomical body composition during the life of the animal (Walstra, 1980). In certain conditions, increasing energy intake increases the protein and the fat deposition (Bikker et al. 1994; de Greef et al. 1994). In addition to the amount of nutrients, the nutrient balance also has an influence on fat deposition. By increasing dietary lysine and protein content, Bikker et al. (1994) found an increase in protein and a decrease in fat deposition in pigs fed at 2.5 and $3.0 \times$ maintenance energy requirements. The distribution of protein and fat deposition is also affected by nutrient intake and nutrient balance. Jørgensen et al. (1985) found that subcutaneous fat was more sensitive to increasing energy intake and/or increasing protein intake than muscle fat. Therefore, the partitioning of fat deposition must have a certain degree of priority among tissues.

In the model development, these principles were considered. In the metabolic part of the model, deposition rates of muscle protein and total body fat are predicted. In the anatomical part, these are regarded as the driving force for distribution of deposited fat over muscle, hidebackfat, organs and bone, as well as the protein deposition rate in hide-backfat, bone and organs (see Fig. 1), as described later.

For establishing the equations in the anatomical part of the model, the unpublished results of $\mathrm{P}$ Bikker were used. The chemical body composition of twenty-four pigs fed in a whole fattening period from 20 to $105 \mathrm{~kg}$ body weight was determined. Those animals received 2.2 or $3.7 \times$ maintenance energy intake at a body weight range of $20-45 \mathrm{~kg}$, and $2.2,2.7$ or $3.7 \times$ maintenance energy intake thereafter until $105 \mathrm{~kg}$ body weight. The daily muscle protein and body fat depositions were in the ranges $39-78 \mathrm{~g} / \mathrm{d}$ and $105-295 \mathrm{~g} / \mathrm{d}$ respectively. The relationships between various deposition rates were described by allometry (see Figs 3 and 4). Analogous to the approach of Gerrits et al. (1997) and as discussed by them, rates of protein deposition of organs, bone and hide-backfat were related to rate of muscle protein deposition (see p. 712, Fig. 3, and equations 4.1, 5.1 and 


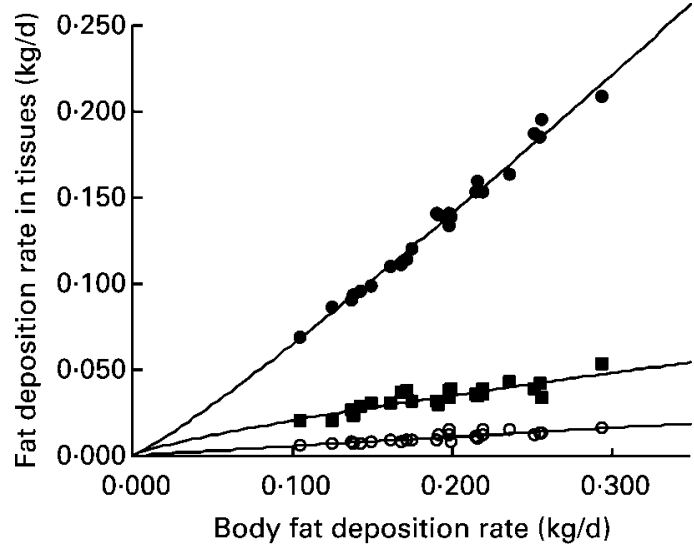

Fig. 4. Partitioning of fat deposition rates in hide-backfat (•), organs (O) and muscle $(\boldsymbol{\Lambda})$ as a function of body fat deposition rate. The relationships were estimated from the data of $P$ Bikker (unpublished results). For details of procedures, see pp. 714-715.

6.1). Fig. 3 illustrates that protein deposition rates in hidebackfat, organs and bone increase with the increasing muscle protein deposition rate, but not in a similar way. It is assumed that at zero muscle protein deposition the total protein mass does not change. At low rates of muscle protein deposition, bone protein deposition has some priority over organ protein (Fig. 3).

According to Kotarbinska (1971) and de Greef (1992), water and ash contents are strongly related to body protein. From the available experimental data, water and ash deposition rates were estimated as a function of protein deposition rate in each fraction (equations 12.2, 12.3).

Whereas the bone protein:fat ratio was considered to be constant, the partitioning of fat deposition over muscle, hide-backfat and organs (for a large part mesenteric fat depots) was considered to be dependent on the rate of fat deposition. As illustrated by Jørgensen et al. (1985) and by $\mathrm{P}$ Bikker (unpublished results), fat distribution across these tissues varies with nutrient intake. In the model, it was decided to make this distribution dependent on the rate of fat deposition, knowing the strong relationship between fat deposition rate and energy (nutrient) intake and assuming that the excess nutrients can be stored as fat, but that the partitioning between tissues depends on the excess to be deposited. The unpublished results of $\mathrm{P}$ Bikker, used to estimate this relationship, confirm this dependency (see Fig. 4). Furthermore, the chemical composition of bone tissue was assumed to be constant (Field et al. 1974), and therefore not sensitive to changes in the rate of body fat deposition. Therefore, the rate of bone fat deposition was made dependent on the rate of bone protein deposition (equation 13.6). It should be mentioned that bone fat content increases with increasing energy intake (Jørgensen et al. 1985), but quantitatively it is not substantial. A pig of $100 \mathrm{~kg}$ body weight has about $8.5 \mathrm{~kg}$ bone (Gu et al. 1992) of which $13-14 \%$ is fat (Just Nielsen, 1973; Jørgensen et al. 1985).

The empty body weight was calculated by summation of protein deposition in muscle, organs, bone and hide-backfat and the deposition rate of fat, water and ash in the total body (equation 12.1). From the experimental data of Bikker et al. (1994, 1995, 1996a,b) the relationship between empty body weight and live weight was obtained (equation 13.1). Liver weight was assumed to be related to the organ protein mass (equation 13.2). The anatomical body composition is calculated by summation of protein, fat, water and ash mass in muscle (equation 14.1), organs (equation 14.2), hide-backfat (equation 14.3) and bone (equation 14.4). Lean mass can be calculated by adding muscle and bone mass (equation 14.5), and carcass is the lean and the hide-backfat together (equation 14.6). The protein and fat mass in lean and carcass can be obtained in a similar way (equations 14.7, 14.8, 14.9 and 14.10).

\section{Model calibration}

For calibration purposes, two complete experiments were selected. The advantages of the experiments for modelling were the following. (1) These trials were carried out with large variations in protein and energy intakes. (2) The measurements were done over a large range of body weight. (3) Measurements of chemical and anatomical composition were included.

\section{Experimental data}

The present pig growth model was calibrated on experimental data of 195 individually housed gilts of a commercial strain (VOC; Nieuw-Dalland, Venray, The Netherlands) (Bikker et al. 1994, 1995, 1996a,b; P Bikker, unpublished results). These animals had been used in two experiments with these aims: (1) to determine the optimal ileal digestible lysine:digestible energy ratio for growing pigs (Bikker et al. 1994); (2) to study the effect of energy intake on tissue deposition and body composition in growing and fattening pigs (Bikker et al. 1995, $1996 a, b)$. The experimental diets were based on maize and soyabean meal. In the first experiment, ninety-five gilts from 20 to $45 \mathrm{~kg}$ body weight were used and pigs were fed at 2.5 or $3.0 \times$ maintenance energy requirements (Agricultural Research Council, 1981). At each of the two digestible energy intakes, lysine intake was increased from 6.4 to $18.2 \mathrm{~g} / \mathrm{d}$ ileal digestible lysine in fifteen steps. For calibration purposes, dietary contents and nutrient digestibility were adopted from Bikker et al. (1994). The gilts were slaughtered at 20 (initial slaughter group) or $45 \mathrm{~kg}$ body weight and dissected into organ and carcass fractions. The slaughter procedures and the carcass analysis are given by Bikker et al. (1994). The equations to obtain the partitioning of protein, fat, water and ash among muscle, hide-backfat and bone in the carcass were adopted from the second experiment.

The second experiment included two feeding periods with 100 pigs. Twenty-eight gilts of $20 \mathrm{~kg}$ body weight were assigned to a reference group and to one of six dietary treatments. The pigs were fed a diet, constant in composition, at intakes increasing from 1.7 to 4.2 (ad libitum) $\times$ maintenance energy requirement. All gilts of dietary treatments were slaughtered at the end of the grower period ( $45 \mathrm{~kg}$ body weight). A further seventy-two gilts were used to represent the growing and fattening period with initial body weight of $20 \mathrm{~kg}$. These animals were fed 2.2 or $3.7 \times$ maintenance energy requirements up to 
$45 \mathrm{~kg}$ body weight. From $45 \mathrm{~kg}$ live weight the pigs received one of six dietary treatments from 1.7 to 4.2 (ad libitum $) \times$ maintenance energy requirements. In this way, pigs $>45 \mathrm{~kg}$ body weight had one of two different feeding histories. Data on digestible nutrient contents and daily feed intake of these animals were available. Gilts were slaughtered at 20 (reference initial slaughter group) or at 45,85 or $105 \mathrm{~kg}$ body weight. Pigs were dissected into organ and blood, fat (hide and subcutaneous fat) and lean (including bone) fractions as described by Bikker et al. $(1995,1996 a, b)$.

\section{Numerical solution}

The growth model was developed in SMART (Kramer \& Scholten, 2003). A complete listing of the equations that constitute the model is given in appendix 1. The differential equations for the lysine, acetyl-CoA, glucose, fatty acids, VFA, muscle protein and body fat state variables are solved numerically for a given set of initial conditions and parameter values. The integration interval used was $0.01 \mathrm{~d}$, with the fourth-order fixed-step-length Runge-Kutta algorithm. The simulated nutrient inputs were continuous, with a predefined amount of daily intake. All the steepness parameters, affinity and inhibition constants were adjusted step by step to obtain a good fit of the experimental data. The response of muscle protein and body fat deposition rates on different nutrient intakes were considered in different weight ranges and in the whole fattening period. The results presented are not sensitive to small changes in initial conditions and smaller integration step sizes.

\section{Results and discussion}

The general model behaviour shows that the metabolite pool sizes are small and comparable with metabolite pool sizes in plasma and body fluids chosen for initial values. There are two storage pools among the state variables: muscle protein and body fat mass. These two parameters are the link between the metabolic and anatomical part of the model. The equations in the anatomical part determine the body composition and subsequently the body weight. Consequently, muscle protein and body fat deposition rates were focused on in the model calibration. The simulated daily muscle protein and body fat deposition in a certain body weight range has to correspond to experimental data. The growth model was calibrated simultaneously on different data sets, originating from different experiments as described earlier. Therefore the variations due to differences in nutrient intake and age from other inter-experimental variations have to be separated. The main aim is to predict differences in performance due to variation in nutrient intake and age accurately; achieving a good prediction of absolute levels of fat and muscle protein deposition rates is of secondary importance.

The observed and simulated responses to increasing ileal digestible lysine intake of the calibration data set of Bikker et al. (1994) are presented in Fig. 5. Overall, the increase in muscle protein deposition rate and decrease in total fat deposition rate with increasing ileal digestible lysine or energy intake are simulated satisfactorily. As a result of
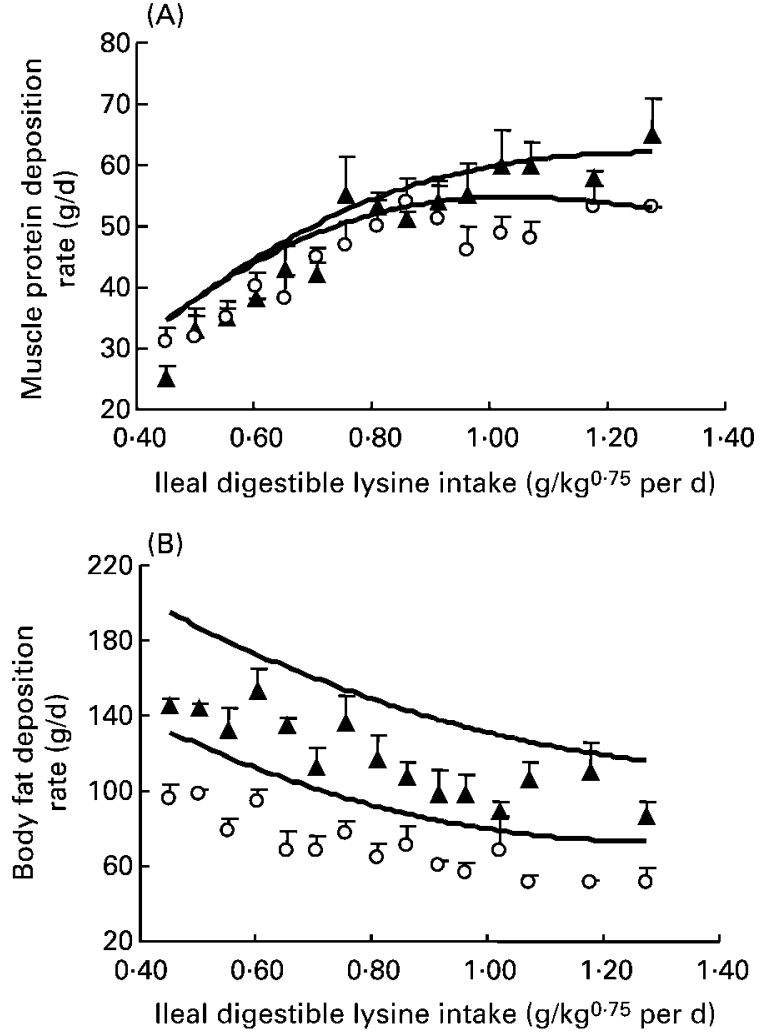

Fig. 5. Simulated $(-)$ and observed $(O, \boldsymbol{\Delta})$ responses of muscle protein $(A)$ and body fat $(B)$ deposition rates of gilts from 20 to $45 \mathrm{~kg}$ body weight to increasing intakes of ileal digestible lysine at different energy intake levels; energy intakes are $3.0(\boldsymbol{\Delta})$ and 2.5 (○) $\times$ maintenance energy requirements, and are constant on a digestible energy basis. Values are means with their standard errors shown by vertical bars. For details of procedures, see p. 716 .

the saturation kinetics in protein synthesis, the protein deposition shows a maximal curve. The increment of protein deposition rate in the muscle decreases with increasing ileal digestible lysine intake and the reduction is different at low and high energy intakes. The muscle protein deposition rate at low lysine intakes is slightly overestimated, whereas at intakes $>0.8 \mathrm{~g} / \mathrm{kg}^{0.75}$ per $\mathrm{d}$ the muscle protein deposition rate fits the observed data. In addition, the contrast in muscle protein deposition rate with increasing energy intake is well predicted. Fat deposition rate is consistently overestimated by the model $(30 \mathrm{~g} / \mathrm{d})$. However, the contrast in fat deposition rate between energy intake levels, as well as the decrease in fat deposition rate with increasing lysine intake is well predicted by the model.

The experimental and simulated effect of energy intake on the muscle protein and body fat deposition in different body weight ranges is given in Figs 6, 7, 8 and 9. In general the model responses are satisfactory regarding the simulated effect of increasing energy intake on muscle protein and body fat deposition rates. The predicted muscle protein deposition rate is slightly underestimated $(5 \mathrm{~g} / \mathrm{d})$ between $20-$ $45 \mathrm{~kg}$ body weight (Fig. 6) and overestimated by $10 \mathrm{~g} / \mathrm{d}$ between $45-85 \mathrm{~kg}$ body weight (Fig. 7). The predicted body fat deposition rate is overestimated $(22 \mathrm{~g} / \mathrm{d})$ between $20-45 \mathrm{~kg}$ body weight (Fig. 6) and underestimated by $15 \mathrm{~g} / \mathrm{d}$ between $45-85 \mathrm{~kg}$ body weight (Fig. 7). Bikker et al. 


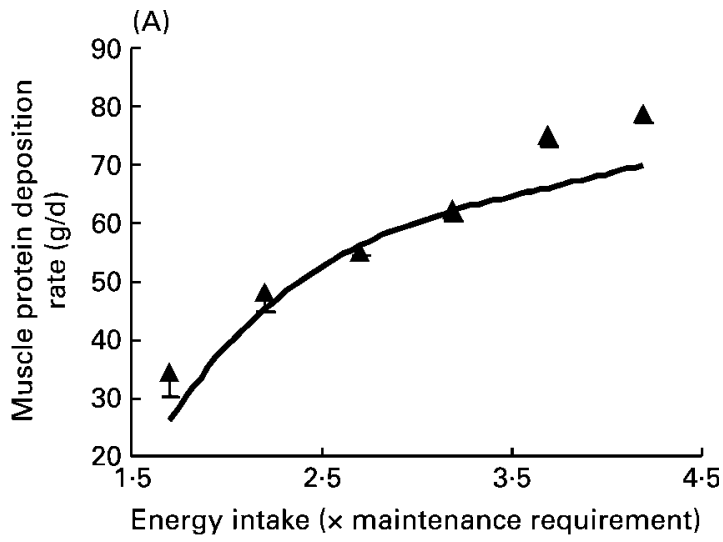

(B)

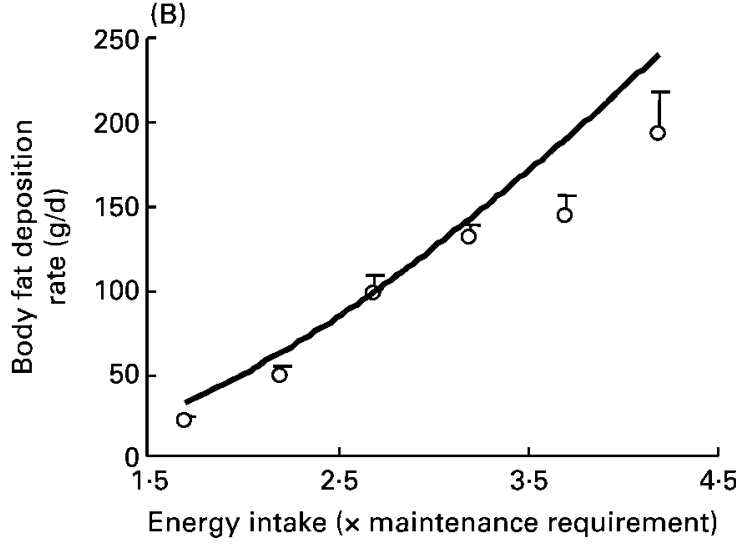

Fig. 6. Simulated $(-)$ and observed $(\Lambda, O)$ responses of muscle protein $(A)$ and body fat $(B)$ deposition rates of gilts from 20 to $45 \mathrm{~kg}$ body weight to increasing energy intake. Values are means with their standard errors shown by vertical bars. For details of procedures, see pp. $716-717$.

$(1995,1996 a, b)$ suggested that the protein deposition increases linearly with energy intake (with a constant composition) in weight ranges of $20-45 \mathrm{~kg}$ and $45-85 \mathrm{~kg}$ body weight (Figs 6 and 7). In contrast, the model predicts a curvilinear response of protein deposition to energy intake, since at high energy intake the muscle protein deposition rate is close to its maximum. Within the theory it is possible, especially in the second period $(45-85 \mathrm{~kg})$ when the feed intake capacity is high and hence the energy supply allows achievement of the potential protein accretion rate. In agreement with that assumption, Dunshea et al. (1998) found a quadratic response of protein deposition to digestible energy intake in $60-90 \mathrm{~kg}$ pigs. The underestimation of muscle protein deposition rates at 3.7 and $4.2 \times$ maintenance energy intake results in an overestimation in body fat deposition between 20 and $45 \mathrm{~kg}$ body weight (Fig. 6). The prediction of the body fat deposition in the later period is in accordance with the observed values (Fig. 7).

The effect of energy intake between 20 and $85 \mathrm{~kg}$ body weight is presented in Fig. 8. During the $20-45 \mathrm{~kg}$ period, the high-energy groups were fed $3.7 \times$ maintenance energy requirement and the low-energy groups were fed $2.2 \times$ maintenance energy requirement. From $45 \mathrm{~kg}$ body weight the energy supply varied from $1.7 \times$ maintenance energy requirement to ad libitum feed intake. The overall prediction is perfect in this weight range. The mean

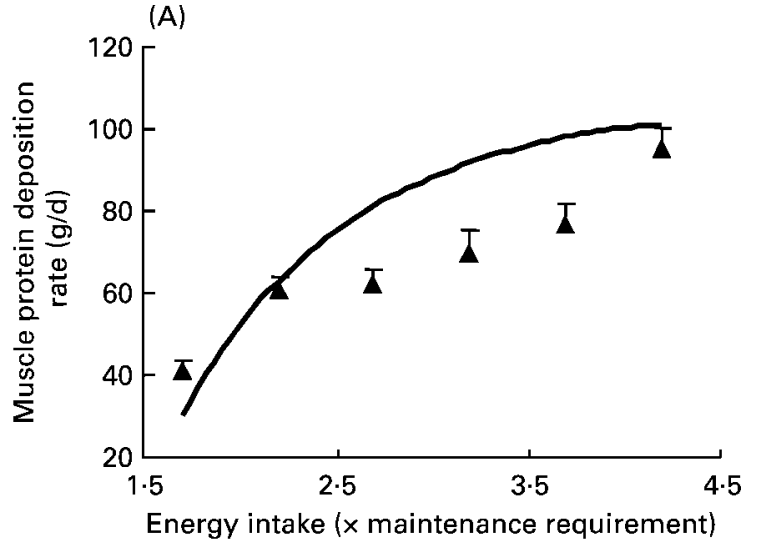

(B)

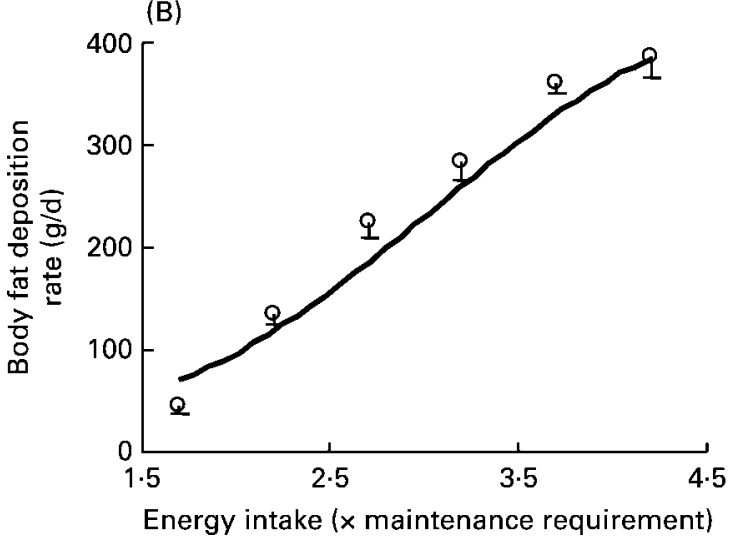

Fig. 7. Simulated $(-)$ and observed $(\boldsymbol{\Lambda}, O)$ responses of muscle protein $(A)$ and body fat $(B)$ deposition rates of gilts from 45 to $85 \mathrm{~kg}$ body weight to increasing energy intake. Values are means with their standard errors shown by vertical bars. For details of procedures, see pp. 716-717.

deviation of predictions from observations are 2 and $1 \mathrm{~g} / \mathrm{d}$ for muscle protein and body fat deposition rates respectively. The observed data for muscle protein deposition at $20-85 \mathrm{~kg}$ body weight suggest a plateau, and the simulations also clearly indicate that plateau. The model predicts the fat deposition accurately, as can be seen in Fig. 8 .

For the entire fattening period $(20-105 \mathrm{~kg})$, the number of treatments was limited. Only three energy intake levels with two feeding histories were studied (P Bikker, unpublished results). The prediction of muscle protein and body fat deposition are less well related than in the weight range of $20-85 \mathrm{~kg}$ (Fig. 9). In general the daily muscle protein deposition is slightly overestimated $(8 \mathrm{~g} / \mathrm{d})$, while the daily body fat deposition is underestimated by $25 \mathrm{~g} / \mathrm{d}$. The reason for the deviation was that the observed muscle protein deposition rate was not increased as a result of an increase in energy intake level at the pigs received low feeding level between $20-45 \mathrm{~kg}$ body weight. The model predicts an increase in deposition rate at both energy intake levels. Consequently, total fat deposition was underestimated in pigs with a low feeding level at growing period. The high feeding level at the growing period resulted in a higher deposition rate in muscle protein and body fat as well.

A summary of observed and predicted values of all experiments is presented in Fig. 10. The results show 
(A)

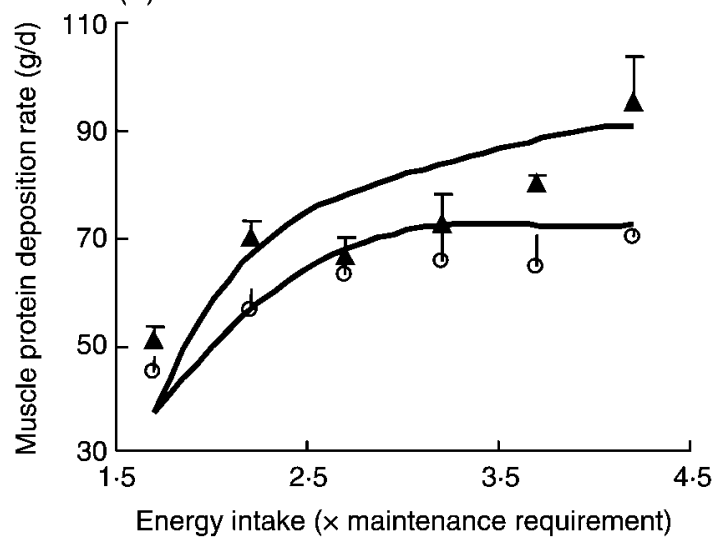

(B)

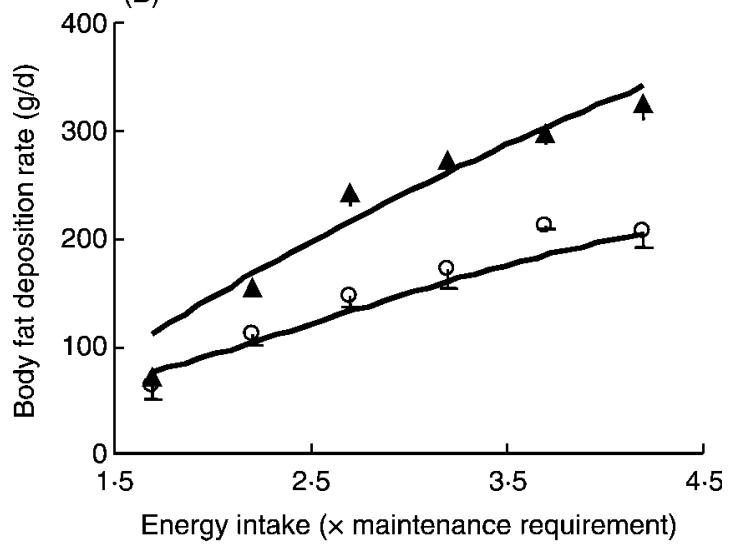

Fig. 8. Simulated (-) and observed responses of muscle protein (A) and body fat (B) deposition rates of gilts from 20 to $85 \mathrm{~kg}$ body weight to increasing energy intake; feeding levels between 20 and $45 \mathrm{~kg}$ are $2.2(\mathrm{O})$ and $3.7(\boldsymbol{\Delta}) \times$ maintenance energy requirements. Values are means with their standard errors shown by vertical bars. For details of procedures, see p. 717.

that the model gives a good prediction in general. The regression line for simulated $v$. observed data for muscle protein deposition rate is $y=1.025 x+2 \cdot 32\left(R^{2} 0 \cdot 815\right)$ and for total body fat deposition rate is $y=0.829 x+35.6$ $\left(R^{2}\right.$ 0.902). The deviation of body fat deposition rate from the regression being 1 increased according to the consistently overestimated fat deposition rates in the first study (see Fig. 5). However, in the same weight range (20$45 \mathrm{~kg}$ ) the daily fat deposition was well estimated in the second experiment (see Fig. 6). It can be concluded that the general response to changes in nutrient intake and age are normal and prediction of contrasts is quantitatively satisfactory. The difference in the accuracy of the model prediction is probably derived from the inter-experimental variation.

\section{Practical application}

There are some restrictions in the application of the present model. The growth model was developed on the data basis of gilts weighing $20-105 \mathrm{~kg}$. Subsequently the model is valid for growing and fattening female pigs, but not for heavy pigs. Considering that lysine is the driving variable in protein synthesis, the model is valid only in feeding
(A)

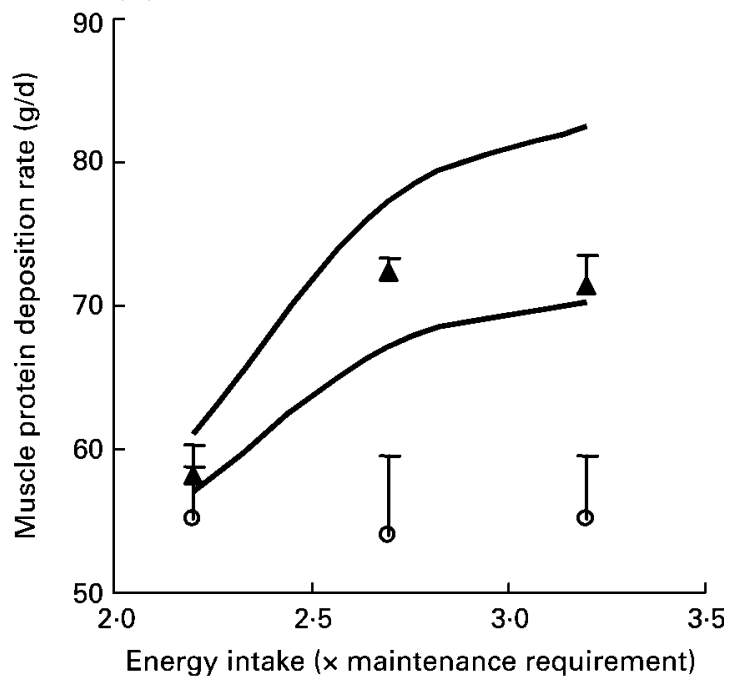

(B)

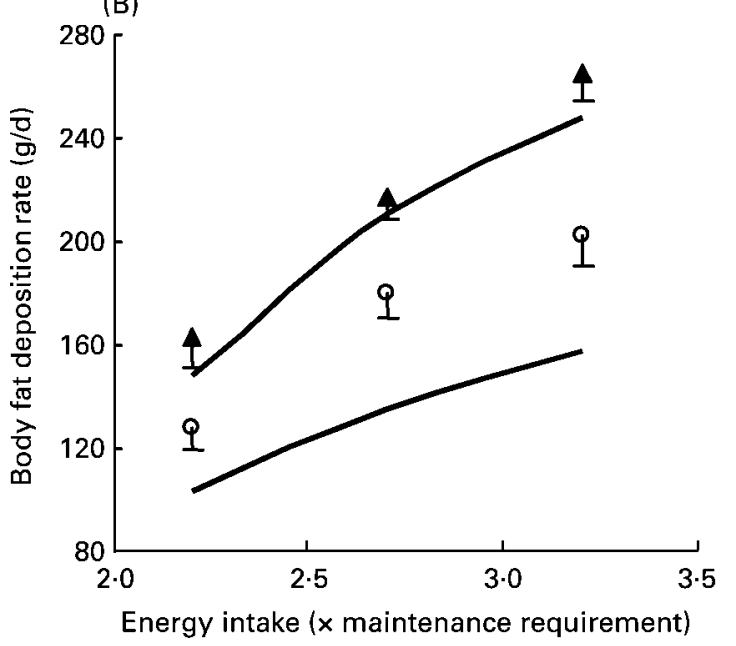

Fig. 9. Simulated (-) and observed responses of muscle protein (A) and body fat (B) deposition rates of gilts from 20 to $105 \mathrm{~kg}$ body weight to increasing energy intake; feeding levels between 20 and $45 \mathrm{~kg}$ are $2.2(\mathrm{O})$ and $3.7(\mathbf{\Lambda}) \times$ maintenance energy requirements. Values are means with their standard errors shown by vertical bars. For details of procedures, see p. 717.

situations when lysine is the limiting amino acid. The present model may operate crudely at extremely low feeding levels (some above maintenance energy intake). The predictions of responses were developed on a daily basis, so it cannot predict the within-day variation in metabolic responses. The model needs separate calibration on other genotypes and genders (castrates, entire males). The growth model was developed from the data for pigs kept under optimal environmental conditions and therefore may not respond appropriately to changes in nutrient inputs under poor environmental conditions and/or low health status.

For effective application of pig growth models, it should be taken into account that there are different genders and genotypes. Representation of genders and genotypes in our approach is in kinetic parameters, particularly $V_{\max }$. Manipulation of the $V_{\max }$ of protein and fat synthesis and amino acid oxidation results in changed protein and fat 
(A)
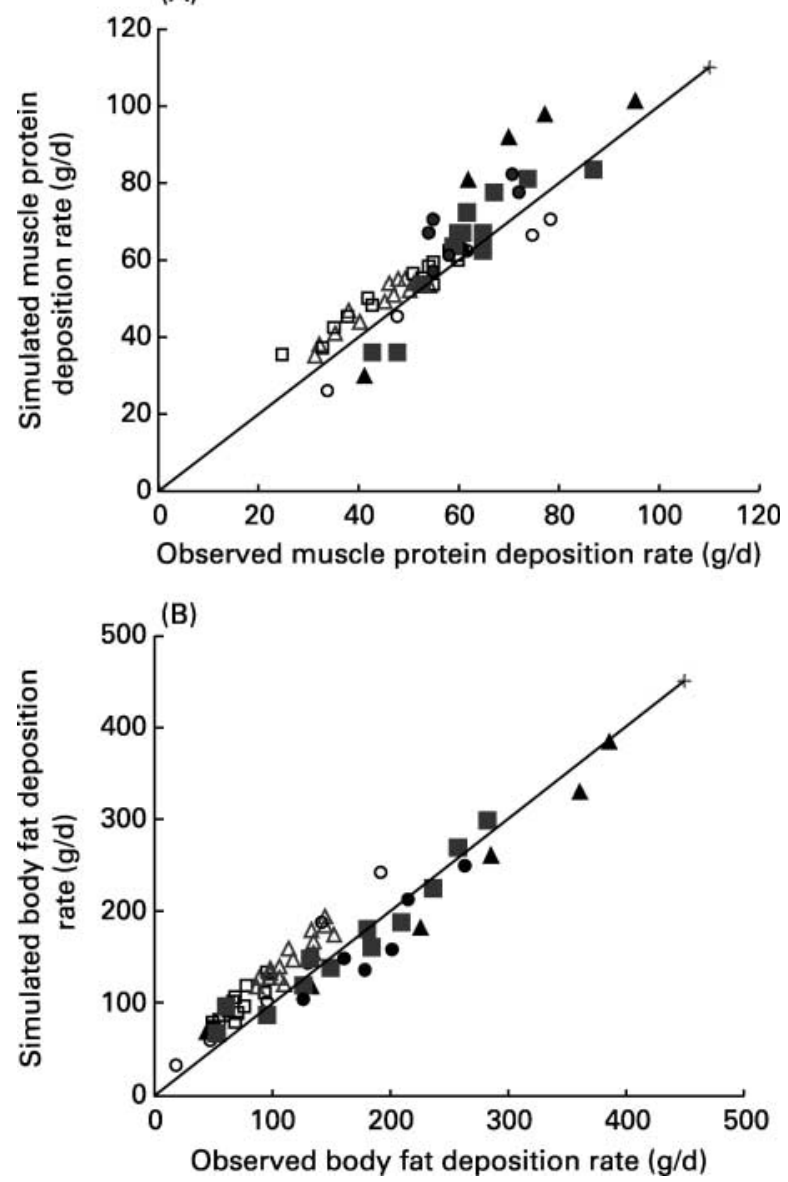

Fig. 10. Agreement of the observations and model simulation in different studies regarding muscle protein (A) and body fat (B) deposition. Different ileal digestible lysine intake at $2.5 \times$ maintenance energy requirement between 20 and $45 \mathrm{~kg}(\triangle)$, different ileal digestible lysine intake at $3.0 \times$ maintenance energy requirement between 20 and $45 \mathrm{~kg}(\square)$, different energy intake between 20 and $45 \mathrm{~kg}(0)$, different energy intake between 45 and $85 \mathrm{~kg}(\mathbf{\Lambda})$, different energy intake between 20 and $85 \mathrm{~kg}(\boldsymbol{\square})$, different energy intake between 20 and $105 \mathrm{~kg}(\bullet)$. For details of procedures, see pp. 717-718.

deposition and different chemical body composition at slaughter. The FDR of muscle protein could be a tool to change the daily protein deposition rates. In rats (Bates \& Milward, 1981) and in chicks (Maruyama et al. 1978; Jones et al. 1986) the FDR of muscle protein was lower in fast-growing $v$. slow growing animals. Therefore, the growth model needs re-calibration on these (genotype sensitive) parameters for each genotype. In addition, the muscle:bone ratio may be different, as confirmed by Quiniou \& Noblet (1995). In addition, the location of the fat (therefore the allometric equations used) may well be different. As reported in the literature, the maintenance energy requirements of different strains and genders are different (Agricultural Research Council, 1981; Whittemore, 1983; Noblet et al. 1999). Maintenance energy requirement, as affected by differences in body composition (metabolically active tissues), is already represented by the model. It has to be noted, however, that re-calibration of the growth model needs good data sets.
In summary, the present paper describes a dynamic mechanistic pig model. The model was calibrated to predict growth rate and body composition of gilts to a wide range of digestible nutrient supply over the entire growing-fattening period. Generally, model predictions of protein and fat deposition rates to changes in digestible nutrient intake at various weight ranges compared well with these complex experimental data. General model behaviour, sensitivity of model predictions to changing parameters and a comparison with independent experimental data are the topic of a companion paper (Halas et al. 2004).

\section{References}

Agricultural Research Council (1981) The Nutrient Requirements of Pigs. London: Commonwealth Agricultural Bureaux.

Baldwin L, France J \& Gill M (1987) Metabolism of the lactating cow I. Animal elements of a mechanistic model. J Dairy Res 54, 77-105.

Bastianelli D, Sauvant D \& Rerat A (1996) Mathematical modelling of digestion and nutrient absorption in the pig. J Anim Sci 74, 1873-1887.

Bates PC \& Milward DJ (1981) Characteristics of skeletal muscle growth and protein turnover in fast growing rat strains. $\mathrm{Br} \mathrm{J}$ Nutr 46, 7-13.

Bergen WG, Johnson SE, Skjaerlund DM, Babiker AS, Ames NK, Merkel RA \& Anderson DB (1989) Muscle protein metabolism in finishing pigs fed ractopamine. J Anim Sci 67, 2255-2262.

Bikker P, Karabinas V, Versegen MWA \& Campbell RG (1995) Protein and lipid accretion in body components of growing gilts $(20-45 \mathrm{~kg})$ as affected by energy intake. J Anim Sci 73, $2355-2363$.

Bikker P, Verstegen MWA \& Campbell RG (1996a) Performance and body composition of fattening gilts $(45-85 \mathrm{~kg})$ as affected by energy intake and nutrition in early life. 2 . Protein and lipid accretion in body components. J Anim Sci 74, 817-826.

Bikker P, Verstegen MWA, Campbell RG \& Kemo B (1994) Digestible lysine requirement of gilts with high genetic potential for lean gain, in relation to the level of energy intake. J Anim Sci 72, 1744-1753.

Bikker P, Verstegen MWA, Kemp B \& Bosch MW (1996b) Performance and body composition of fattening gilts $(45-85 \mathrm{~kg})$ as affected by energy intake and nutrition in early life. 1 . Growth of the body and body compartments. J Anim Sci 74, $806-816$.

Birkett S \& de Lange K (2001a) Limitations of conventional models and conceptual framework for a nutrient flow representation of energy utilization by animals. Br J Nutr 86, 647-659.

Birkett S \& de Lange K (2001b) Calibration of nutrient flow model of energy utilization by growing pigs. Br J Nutr 86, 675-689.

Black JL (1995) The evolution of animal growth models. In Modelling Growth in the Pig, European Association of Animal Production Publication no 78, pp. 3-9 [PJ Moughan, MWA Verstegen and MI Visser-Reyneveld, editors]. Wageningen: Wageningen Pers.

Black PJ, Fleming JF \& Davies GT (1988) AUSPIG: A computer program for the optimal management of pigs. Proc Aust Soc Anim Prod 17, 366.

Burlacu G, Burlacu R, Columbeau I \& Alexandru G (1989) Contributions to the study of the mathematical modelling of energy and protein metabolism simulation in fattening pigs. In Energy Metabolism of Farm Animals, European Association of Animal 
Publication no. 43, pp. 211-214 [Y van de Honig and WH Close, editors]. Wageningen: Pudoc Wageningen.

Campbell RG, Traverner MR \& Curic DM (1984) Effect of feeding level and dietary protein content on the growth, body composition and rate of protein deposition in pigs growing from 45 to $90 \mathrm{~kg}$. Anim Prod 38, 233-240.

Campbell RG, Traverner MR \& Curic DM (1985) The influence of feeding level on the protein requirement of pigs between 20 and $45 \mathrm{~kg}$ live weight. Anim Prod 40, 489-496.

Danfaer A (1999) Carbohydrate and lipid metabolism. In A Quantitative Biology of the Pig, pp. 333-362 [I Kyriazakis, editor]. Wallingford, Oxon.: CAB International.

Danfaer A (2000) A pig model for feed evaluation. In Modelling Nutrient Utilization in Farm Animals, pp. 393-408 [PJ Namara, J France and D Beever, editors]. Wallingford, Oxon.: $\mathrm{CAB}$ International.

Defa L, Changting X, Shiyan Q, Jinhui Z, Jonson EW \& Thacker PA (1999) Effects of dietary threonine on performance, plasma parameters and immune function of growing pigs. Anim Feed Sci Technol 78, 179-188.

De Greef KH (1992) Prediction of production. Nutrition induced tissue partitioning in growing pigs. $\mathrm{PhD}$ Thesis, Wageningen University, pp. 75-104.

De Greef KH, Verstegen MWA, Kemp B \& van der Togt PL (1994) The effect of body weight and energy intake on the composition of deposited tissue in pigs. Anim Prod 58, 263-270.

De Lange CFM (1995) Framework for a simplified model to demonstrate principles of nutrient partitioning for growth in the pig. In Modelling Growth in the Pig. European Association of Animal Production Publication no. 78, pp. 71-86 [PJ Moughan, MWA Verstegen and MI Visser-Reyneveld, editors]. Wageningen: Wageningen Pers.

Dunshea FR, King RH, Eason PJ \& Campbell RG (1998) Interrelationships between dietary ractopamine, energy intake and sex in pigs. Aust J Agric Res 49, 565-574.

Field RA, Riley ML, Mello FC, Corbridge MH \& Kotula AW (1974) Bone composition in cattle, pigs and poultry. J Anim Sci 39, 493-499.

France J, Gill M, Thronley JHM \& England P (1987) A model of nutrient utilization and body composition in beef cattle. Anim Prod 44, 371-385.

Gerrits WJJ \& Dijkstra J (2000) Modelling growth and wool production in ruminants. In Feeding Systems and Feed Evaluation Models, pp. 343-361 [MK Theodorou and J France, editors]. Wallingford, Oxon.: CAB International.

Gerrits WJJ, Dijkstra J \& Frances J (1997) Description of a model integrating protein and energy metabolism in preruminant calves. J Nutr 127, 1229-1242.

Gill M, Beever DE \& France J (1989a) Biochemical bases needed for the mathematical representation of whole animal metabolism. Nutr Res Rev 2, 181-200.

Gill M, France J, Summers M, McBride B \& Milligan LP (1989b) Simulation of the energy costs associated with protein turnover and $\mathrm{Na}^{+}, \mathrm{K}^{+}$-transport in growing lambs. $J$ Nutr 119, $1287-1299$.

Gill M, Thronley JH, Black JL, Oldham JD \& Beever DE (1984) Simulation of the metabolism of absorbed energy-yielding nutrients in young sheep. Br J Nutr 52, 621-649.

Gu Y, Schinckel AP \& Martin TG (1992) Growth, development and carcass composition in five genotypes of swine. J Anim Sci 70, 1719-1729.

Halas V \& Babinszky L (2000) Modelling of performance and protein and fat deposition in pigs: a review. Krmiva 42, 251-260.

Halas V, Babinszky L \& Verstegen MWA (2003) Conceptual paper for modelling protein and lipid accretion in different body parts of growing and fattening pigs. Arch Anim Nutr 57, 137-150.

Halas V, Dijkstra J, Babibszky L, Verstegen MWA \& Gerrits WJJ (2004) Modelling of nutrient partitioning in growing pigs to predict their anatomical composition. 2. Model evaluation. $\mathrm{Br}$ J Nutr 92, 725-734.

Jørgensen JN, Fernández JA, Jørgensen HH \& Just A (1985) Anatomical and chemical composition of female pigs and barrows of Danish Landrace related to nutrition. Z Tierphysiol Tierernahr Futtermittelkd 54, 253-263.

Jones SJ, Aberle ED \& Judge MD (1986) Skeletal muscle protein turnover in broiler and layer chicks. J Anim Sci 62, 1576-1583.

Just Nielsen A (1973) Anatomical and chemical composition of Danish Landrace pigs slaughtered at 90 kilograms live weight in relation to litter, sex and feed composition. J Anim Sci 36, 476-483.

Kennelly JJ, Aherne FX \& Sauer WC (1981) Volatile fatty-acid production in the hindgut of swine. Can J Anim Sci 61, 349-361.

Kotarbinska M (1971) The chemical composition of the body in growing pigs. Roczniki Nauk Rol B-93, 129-135.

Kramer M \& Scholten H (2003) The smart approach to modelling and simulation. In Proceedings of EUROSIM 2001, Shaping Future with Simulation, The 4th International EUROSIM Congress, incorporating the 2nd Conference on Modelling and Simulation in Biology, Medicine and Biomedical Engineering, [AW Heemink, L Dekker, H der S Arons, I Smit and TL van Stijn, editors]. Delft: TU Delft.

Larsen T, Fernández JA \& Engberg RM (2000) Bone turnover in growing pigs fed three levels of dietary calcium. J Anim Sci $\mathbf{8 0}$, 547-557.

Lizardo R, van Milgen J, Mourot J, Noblet J \& Bonneau M (2002) A nutritional model of fatty acid composition in the growingfinishing pig. Livest Prod Sci 75, 167-182.

Lovatto PA \& Sauvant D (2003) Modeling homeorhetic and homeostatic controls of pig growth. J Anim Sci 81, 683-696.

Martin AK \& Blaxter KL (1965) The energy cost of urea synthesis in sheep. In Energy Metabolism, pp. 83-91 [KL Blaxter, editor]. London: Academic Press.

Maruyama K, Stunde ML \& Swick RW (1978) Growth and muscle protein turnover in the chick. Biochem $J$ 176, $573-582$.

Michael P \& Rerat A (1998) Effect of adding sugar beet fiber and wheat bran to a starch diet on the absorption kinetics of glucose, amino-nitrogen and volatile fatty acids in the pig. Reprod Nutr Dev 38, 49-68.

Moughan PJ (1989) Simulation of the daily partitioning of lysine in the $50 \mathrm{~kg}$ liveweight pig - a factorial approach to estimating amino acid requirements for growth and maintenance. Res Dev Agric 6, 7-14.

Moughan PJ, Smith WC \& Pearson G (1987) Description and validation of a model simulating growth in the pig $(20-90 \mathrm{~kg}$ live weight). NZ J Agric Res 30, 481-489.

Mulvaney DR, Merkel RA \& Bergen WG (1985) Skeletal muscle protein turnover in young male pigs. J Nutr 115, 1057-1064.

Nelson DL \& Cox MM (1982) Amino acid oxidation and the production of urea. In Lehninger Principles of Biochemistry, pp. 623-658 [DL Nelson and MM Cox, editors]. New York: Worth Publishers.

Noblet J, Karege C, Dubois S \& van Milgen J (1999) Metabolic utilization of energy and maintenance requirements in growing pigs: effects of sex and genotype. J Anim Sci 77, $1208-1216$

Nürnberg K \& Wegner J (1990) Fatty acid composition and adipocyte diameter of backfat in boars during growth. Arch Tierz. 34, $51-56$. 
Pettigrew JE, Gill M, France J \& Close WH (1992) A mathematical integration of energy and amino acid metabolism of lactating sows. J Anim Sci 70, 3742-3761.

Pomar C, Harris DL \& Minvielle F (1991) Computer simulation model of swine production systems: I. Modeling the growth of young pigs. J Anim Sci 69, 1468-1488.

Quiniou N \& Noblet J (1995) Prediction of tissular body composition from protein and lipid deposition in growing pigs. J Anim Sci 73, 1567-1575.

Rapoport SM, Dubiel W \& Muller M (1985) Proteolysis of mitochondria in reticulicytes during maturation is ubiquitindependent and is accompanied by a high rate of ATP hydrolysis. Eur J Biochem 290, 249-252.

Rathmacher JA, Nissen LS, Paxton RE \& Anderson DB (1996) Estimation of 3-methylhistidine production in pigs by compartmental analysis. J Anim Sci 74, 46-56.

Reeds PJ, Fuller MF \& Nicholson BA (1985) Metabolic bases of energy expenditure with particular reference to protein. In $S u b$ strate and Energy Metabolism in Man, pp. 46-57 [JS Garrow and W Halliday, editors]. London: CRC

Reeds PJ, Nicholson BA \& Fuller MF (1987) Contribution of protein synthesis to energy expenditure in vivo and in vitro. In Energy Metabolism of Farm Animals, Proceedings of the 11th Symposium, European Association for Animal Production Publication no. 32, pp. 6-9 [PW Moe, HF Tyrrell and PJ Reynolds, editors]. Totowa, NJ: Rowman \& Littlefield.

Riis PM (1983) The pool of tissue constituents and products: proteins. In Dynamic Biochemistry of Animal Production, pp. 75-108 [MP Riis, editor]. Copenhagen: Department of Animal Physiology, The Royal Veterinary and Agricultural University.

Rivest J, Bernier JF \& Pomar C (2000) A dynamic model of protein digestion in the small intestine of pigs. J Anim Sci 78, 328-340.

Schinckel AP \& de Lange CFM (1996) Characterization of growth parameters needed as inputs for pig growth models. $J$ Anim Sci 74, 2021-2036.

Simon O (1989) Metabolism of proteins and amino acids. In Protein Metabolism in Farm Animals. Evaluation, Digestion, Absorption, and Metabolism, pp. 273-366 [H-D Bock, OB
Eggum, AG Low, O Simon and T Zebrowska, editors]. Oxford: Oxford University Press.

Smith NE (1970), Modelling studies of ruminant metabolism, $\mathrm{PhD}$ Thesis, University of California, Davis.

Stangl GI, Müller H \& Kirchgessner M (1999) Conjugated linolenic acid effects on circulating hormones, metabolites and lipoproteins, and its proportion in fasting serum and erythrocyte membranes of swine. Eur J Nutr 38, 271-277.

Stryer L (1981) Biochemistry, 2nd ed. San Francisco, CA: Freeman and Company.

Technisch Model Varkensvoeding (1991) Technisch Model Varkensvoeding (Technical Model for Pig Feeding). Infomatiemodel. Research Report P166. Rosmalen: Research Institute for Pig Husbandry.

Van den Hemel-Grooten HN (1996) 3-Methylhistidine production and muscle proteinase activity in growing pigs. PhD Thesis, Wageningen University.

Walstra P (1980) Growth and carcass composition from birth to maturity in relation to feeding level and sex in Dutch Landrace pigs. PhD Thesis, Wageningen University.

Whittemore CT (1983) Development of recommended energy and protein allowances for growing pigs. Agric Syst 11, 159-186.

Whittemore CT \& Fawcet RH (1976) Theoretical aspects of a flexible model to simulate protein and lipid growth in pigs. Anim Prod 22, 87-96.

Wijayasinghe MS, Smith NE \& Baldwin RL (1986) Effects of age, milk replacer and rumen function on lipogenesis and adipose tissue of young calves. J Dairy Sci 69, 2358-2369.

Wünsche J, Borgmann E, Hennig U, Kreienbring F \& Bock F (1983) Einfluss einer abgestuften proteinversorgung bei hohem energienveau auf die mastleistung sowie den ansatz und die verwertung von futterenergie, protein und aminosäuren durch weibliche mastschweine. (The influence of graded protein supply at a high energy level on the fattening performance and the retention and utilization of feed energy, protein and amino acids by female fattening pigs. 4. Nitrogen and amino acid content in the slaughtered bodies and parts of them). Arch Tiernahr 33, 389-413.

\section{Appendix 1}

Mathematical statement of the pig growth model

\section{Protein metabolism \\ Lysine pool, Qly (mol) \\ Concentration:}

Input:

Output:

Differential equation:

Amino acid pool, Qaa (mol) Input:

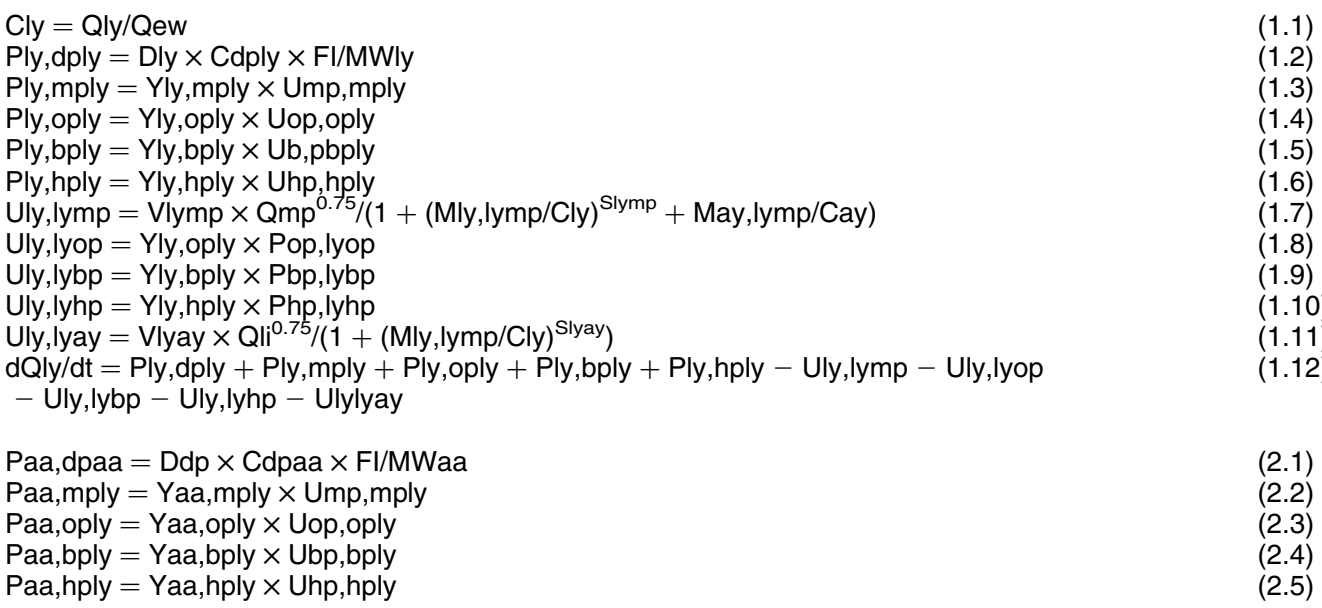


Output:

Uaa,lymp $=$ Raa,lymp $\times$ Uly,lymp

Uaa,lyop $=$ Raa,lyop $\times$ Uly,lyop

Uaa,lybp $=$ Raa,lybp $\times$ Uly,lybp

(2.8)

Uaa,lyhp $=$ Raa,lyhp $\times$ Uly,lyhp

Uaa, aaay $=$ Paa,dpaa + Paa,mply + Paa,oply + Paa,bply + Paa,hply - Uaa,lymp

Differential equation: - Uaa,lyop - Uaa,lybp - Uaa,lyhp

Muscle protein pool, Qmp (kg)

Input:

$\mathrm{dQaa} / \mathrm{dt}=0$

Pmp,lymp $=$ Ymp,lymp $\times$ Uly,lymp

Ump, $\mathrm{mply}=\mathrm{Qmp} \times \mathrm{FDRmp}$

Differential equation:

$\mathrm{dQmp} / \mathrm{dt}=$ Pmp,Iymp - Ump, mply

Organ protein pool, Qop $(\mathrm{kg})$

Input:

Pop,lyop $=0.1822 \times \mathrm{dQmpdt}^{0.8599}+$ Uop,oply

Output:

Uop,oply $=$ Qop $\times$ FDRop

$(4.2)$

Differential equation

$\mathrm{dQop} / \mathrm{dt}=$ Poplyop - Uopoply

-backfat protein pool, Qhp $(\mathrm{kg})$

Input:

Php,lyhp $=0.4269 \times \mathrm{dQmpdt}^{0.8716}+$ Uhp,hply + Uhp,hpex

Uhp,hply $=$ Qhp $\times$ FDRhp

Uhp, hpex $=0.094 \times$ Qew $^{0.75} / 1000$

$(5.3)$

Differential equation: Bone protein pool, Qbp $(\mathrm{kg})$ Input:

Output:

Differential equation:

Energy metabolism

Acetyl Co-A pool, Qay (mol)

Concentration:

$\mathrm{dQhp} / \mathrm{dt}=$ Php,lyhp - Uhp,hply - Uhp,hpex

Pbp,lybp $=0.0793 \times \mathrm{dQmpdt}^{0.6621}+$ Ubp, bply

Ubp,bply $=$ Qbp $\times$ FDRbp

$\mathrm{dQbp} / \mathrm{dt}=$ Pbp,lybp - Ubp, bply

Cay $=$ Qay/Qew

Pay,lyay $=$ Yay,lyay $\times$ Uly,lyay

Pay,aaay $=$ Yay, aaay $\times$ Uaa,aaay

Pay,faay $=$ Yay,faay $\times$ Ufa,faay

Pay,glay $=$ Yay,glay $\times$ Ugl,glay

Pay, vfay $=$ Yay, vfay $\times$ Uvf,vfay

Output:

Uay,ayfa $=$ Vayfa $\times \mathrm{Qtf}^{0.75} /(1+$ May,ayfa/Cay + Cfa/Jfa,ayfa $)$

Uay,ayma $^{\#}=$ Uay, ayma $\times 0.80-($ Pat,lyay + Pat,aaay + Pat,dfgl + Pat,glay

Uay, ayox $=($ Ray,lymp + Ray, aamp $\times$ Raa,lymp $) \times$ Uly,lymp

+ (Ray,lyop + Ray, aaop $\times$ Raa,lyop) $\times$ Uly,lyop + (Ray,lybp + Ray,aabp $\times$ Raa,lybp

$\times$ Uly,lybp + (Ray,lyhp + Ray,aahp $\times$ Raa,lyhp) $\times$ Uly,lyhp + Ray,fatf $\times$ Ufa,fatf

$+($ Ray,mply + Ray,mpaa) $\times$ Ump,mply + (Ray,oply + Ray,opaa) $\times$ Uop,oply

+ (Ray,bply + Ray,bpaa) $\times$ Ubp, bply + (Ray,hply + Ray,hpaa) $\times$ Uhp, hply

+ Ply,dply $\times$ Aly + Paa,dpaa $\times$ Aaa $+($ Pgl,stgl + Pgl,sugl + Pgl,dffa $)$

$\times \mathrm{Agl}+$ Pfa,dffa $\times$ Afa + Ray,lyun $\times$ Uly,lyun + Ray,aaun

$\times$ Uaa,aaun + Ray, data $\times 0.0855^{*} \times(\mathrm{dQmpdt}+\mathrm{dQopdt}+\mathrm{dQbpdt}+\mathrm{dQhpdt})^{0.6215}$

Uay, aygr $=$ Vaygr $^{*} \times$ Qew $^{0.67} /(1+$ May,aygr/Cay + Mly,aygr/Cly $)$

Differential equation:

$\mathrm{dQay} / \mathrm{dt}=$ Pay,lyay + Pay,aaay + Pay,faay + Pay,glay + Pay,vfay - Uay,ayfa

- Uay,ayma - Uay,ayox - Uay,aygr

Uay, ayma $=0.836 \times(\mathrm{Qmp}+\mathrm{Qbp}+\mathrm{Qhp})^{0.75}+4.231 \times \mathrm{Qop}^{0.75}+0.113 \times \mathrm{Qtf} \mathrm{f}^{0.75}$

Auxiliary equations:

Pat,lyay $=$ Yat,lyay $\times$ Uly,lyay

Pat, aaay $=$ Yat, aaay $\times$ Uaa, aaay

Pat, dfgl $=$ Yat, dfgl $\times$ Ddf $\times$ Cdf $\times \mathrm{Fl} / 1000$

$(7.13)$

$(7.14)$

$(7.15)$

Pat,glay $=$ Yat,glay $\times$ Ugl,glay

Pat,tfgl $=$ Yat,tfgl $\times$ Utf, tffa

$(7.16)$

Pat,faay $=$ Yat,faay $\times$ Ufa,faay

$(7.17)$

Uly,lyun $=$ Yun,lyay $\times$ Uly,lyay

(7.18)

Uaa, aaun $=$ Yun,aaay $\times$ Uaa, aaay

VFA pool, Qvf (mol) Concentration:

$\mathrm{Cvf}=\mathrm{Qvf} / \mathrm{Qew}$

Pvf, cwvf $=$ Dcw $\times$ Ccw $\times$ FI $\times$ Yvf, cwvf $/ 1000$

$(8.2)$

Uvf,vfay $=$ Vvfay $\times \mathrm{Qew}^{0.75} \times \mathrm{PRayvf} /(1+(\mathrm{Mvf}, \mathrm{vfay} / \mathrm{Cvf})$

Output:

Differential equation:

Glucose pool, Qgl (mol) Concentration:

Uvf,vfgl $=U v$,fvfay $\times(1-$ PRayvf $) / P R a y v f$

$\mathrm{dQvf} / \mathrm{dt}=\mathrm{Pvf}, \mathrm{cwvf}-\mathrm{Uvf}, \mathrm{vfay}-\mathrm{Uvf}, \mathrm{vfg}$

$\mathrm{Cgl}=\mathrm{Qgl} / \mathrm{Qew}$

$\mathrm{Pgl}$, stgl $=$ Dst $\times$ Cst $\times \mathrm{FI} \times \mathrm{Ygl}$, stgl $/ 1000$

$\mathrm{Pgl}$, sugl $=$ Dsu $\times \mathrm{Csu} \times \mathrm{FI} \times \mathrm{Ygl}$,sugl/1000

Pgldffa $=$ Ddf $\times$ Cdf $\times \mathrm{FI} \times$ Ygl,dffa/1000

$\mathrm{Pgl}, \mathrm{vfgl}=\mathrm{Ygl}, \mathrm{vfgl} \times \mathrm{Uvf,vfg}$

$\mathrm{Pgl}, \mathrm{tffa}=$ Ygl,tffa $\times \mathrm{Utf}, \mathrm{tffa}$

Output:

Ugl,glay $=$ Vglay $\times$ Qew $^{0.75} /(1+(\mathrm{Mgl}$,glay/Cgl $)$

Ugl,ayfa $=$ Rgl,ayfa $\times$ Uay, ayfa

Ugl,fatf $=$ Rgl,fatf $\times$ Ufa,fat

Differential equation: 
Fatty acid pool, Qfa (mol) Concentration:

Input:

Output:

Differential equation:

Body fat pool, Qtf (kg)

Input:

Output:

Differential equation:

Summative equations

Empty body weight, Qew (kg)

Body water mass, Qtw (kg)

Body ash mass, Qta (kg)

\section{Other equations}

Live weight, Qlw (kg)

Liver weight, Qli (kg)

Hide-backfat fat, Qhf (kg)

Muscle fat, Qmf $(\mathrm{kg})$

Organ fat, Qof $(\mathrm{kg})$

Bone fat, Qbf $(\mathrm{kg})$

Anatomical composition

Muscle mass, Qmm (kg)

Organ mass, Qom (kg)

Hide-backfat mass, Qhm (kg)

Bone mass, Qbm (kg)

Lean mass, QIm $(\mathrm{kg})$

Carcass mass, Qcm (kg)

Lean protein, Qlp $(\mathrm{kg})$

Lean fat, Qlf $(\mathrm{kg})$

Carcass protein, Qcp (kg)

Carcass fat, Qcf (kg)
$\mathrm{Cfa}=\mathrm{Qfa} / \mathrm{Qew}$

$\mathrm{Pfa}, \mathrm{dffa}=\mathrm{Ddf} \times \mathrm{Cdf} \times \mathrm{FI} \times \mathrm{Yfa}, \mathrm{dffa} / 1000$

Pfa,tffa $=$ Yfa,tffa $\times$ Utf,tffa

Pfa,ayfa = Yfa,ayfa $\times$ Uay,ayfa

Ufa,fatf $=$ Vfatf $\times$ Qtf $/(1+($ Mfa,fatf $/ C f a)$

Ufa,faay $=$ Vfaay $\times$ Qew ${ }^{0.75} /(1+$ Mfa,faay/Cfa + Cay/Jay,faay $)$

$\mathrm{dQfa} / \mathrm{dt}=\mathrm{Pfa}, \mathrm{dffa}+\mathrm{Pfa}, \mathrm{tffa}+\mathrm{Pfa}, \mathrm{ayfa}-\mathrm{Ufa}, \mathrm{fatf}-\mathrm{Ufa}, \mathrm{faay}$

Ptf,fatf $=$ Ytf,fatf $\times$ Ufa,fatf

Utf,tffa $=$ Qtf $\times$ FDRtf

$\mathrm{dQtf} / \mathrm{dt}=$ Ptf,fatf - Utf,tffa

$(10.1)$

$(10.2)$

(10.3)

$(10.4)$

$(10.5)$

(10.6)

(10.7)

(11.1)

(11.2)

(11.3)

$\mathrm{dQew} / \mathrm{dt}=\mathrm{dQmp} / \mathrm{dt}+\mathrm{dQop} / \mathrm{dt}+\mathrm{dQhp} / \mathrm{dt}+\mathrm{dQbp} / \mathrm{dt}+\mathrm{dQtf} / \mathrm{dt}+\mathrm{dQtw} / \mathrm{dt}+\mathrm{dQta} / \mathrm{dt}$

$\mathrm{dQtw} / \mathrm{dt}=4.6279 \times(\mathrm{dQmp} / \mathrm{dt})^{1.109}+5.1138 \times(\mathrm{dQop} / \mathrm{dt})^{1.0407}+1.3169$

$\times(\mathrm{dQhp} / \mathrm{dt})^{0.7682}+1.896 \times(\mathrm{dQbp} / \mathrm{dt})^{1.005}$

$\mathrm{dQta} / \mathrm{dt}=0.0534 \times(\mathrm{dQmp} / \mathrm{dt})^{1.0355}+0.0985 \times(\mathrm{dQop} / \mathrm{dt})^{1.1359}+0.0258$

$\times(\mathrm{dQhp} / \mathrm{dt})^{0.7597}+1.2503 \times(\mathrm{dQbp} / \mathrm{dt})^{0.9963}$

$\mathrm{Qlw}=1.287 \times \mathrm{Qew}^{0.9531}$

Qli $=\exp (1-1 /$ Qop)

$(13.2)$

$(13.3)$

$\mathrm{dQmf} / \mathrm{dt}=0.1217 \times(\mathrm{dQtf} / \mathrm{dt})^{0.7704}$

$\mathrm{dQmf} / \mathrm{dt}=0.1217 \times(\mathrm{dQtf} / \mathrm{dt})$
$\mathrm{dQof} / \mathrm{dt}=0.0519 \times(\mathrm{dQtf} / \mathrm{dt})^{0.9584}$

$\mathrm{dQbf} / \mathrm{dt}=0.9074 \times(\mathrm{dQbp} / \mathrm{dt})^{1.0091}$

$\mathrm{dQmm} / \mathrm{dt}=\mathrm{dQmp} / \mathrm{dt}+\mathrm{dQmf} / \mathrm{dt}+4.6279 \times(\mathrm{dQmp} / \mathrm{dt})^{1.109}+0.0534 \times(\mathrm{dQmp} / \mathrm{dt})^{1.0355}$

$\mathrm{dQom} / \mathrm{dt}=\mathrm{dQop} / \mathrm{dt}+\mathrm{dQof} / \mathrm{dt}+5.1138 \times(\mathrm{dQop} / \mathrm{dt})^{1.0407}+0.0985 \times(\mathrm{dQop} / \mathrm{dt})^{1.1359}$

$\mathrm{dQhm} / \mathrm{dt}=\mathrm{dQhp} / \mathrm{dt}+\mathrm{dQhf} / \mathrm{dt}+1.3169 \times(\mathrm{dQhp} / \mathrm{dt})^{0.7682}+0.0258 \times(\mathrm{dQhp} / \mathrm{dt})^{0.7597}$

$\mathrm{dQbm} / \mathrm{dt}=\mathrm{dQbp} / \mathrm{dt}+\mathrm{dQbf} / \mathrm{dt}+1.896 \times(\mathrm{dQbp} / \mathrm{dt})^{1.0051}+1.2503 \times(\mathrm{dQbp} / \mathrm{dt})^{0.9963}$

$(14.5)$

$\mathrm{Qcm}=\mathrm{Qlm}+\mathrm{Qhm}$

$\mathrm{Qlp}=\mathrm{Qmp}+\mathrm{Qbp}$

$\mathrm{Qlf}=\mathrm{Qmf}+\mathrm{Qbf}$

$\mathrm{Qcp}=\mathrm{Qlp}+\mathrm{Qhp}$

$\mathrm{Qcf}=\mathrm{Qlf}+\mathrm{Qhf}$

$\mathrm{FI}$, feed intake. 